\title{
On the causes of "bigh water" in the Northern Adriatic Sea, with special reference to the Venice Lagoon
}

\author{
P. ChLOI \\ Received on Januar, 5 th, 1973
}

Semmar. - It is a wirlespreat belief of experts that the reatsons of the increased frequencF of "high waters" in the Iagoon of Venice are limited to the gradual sinking of the area (in connection with disorderly under. ground extractions of water) and to bradiscism of the West coast of the High Adriatic Sea.

Aetually, the lligh Arriatic is envolvex in a process of slow filling caused by the enomous anomt of erosion products dragged into it by tens of rivers flowing into it. This material reaches exceptional proportions in flood periods, especially of the P'o River. The resulting raise of the sea bottou excecls on the whole the effect of eustatism and bradiseism. Thus, the lyylrodynanic balance of the Crulf of Venice is subjected to continuous changes, which means that by continuous, very slow thimning out of the water thickness the water is bound the other conditions remaining unvaried) to increase slowly the amplitule of its free, forced or progressive movements and to increase slowly, but progressively the period of its free oscillations. This latter aspect is particularly intriguing if one considers that the free oscillations of about 11.7 hours and 23 hours tend, extremely slowly though, to coincirle with the rhythm of the half-daily and daily titles and thus accentuate the losonance efiect in the course of time.

It was foumd that beginuing with 1940 the earth's mean air temperature, which was slightly rising since 1880 , inverted its tendency. In spite of reducing the enstatic effects, the temperature reduction gave rise to a progressive increase of precipitations which led to an accentuation of the of ficiency of natural causes governing the high waters. Jast but not least of the latter is the "lightening" of the sea che to reduced salinity, accompanied by a decrease of density, of molecular viseosity and of surface tension. It is responsible of isostatic effects, of easing and strengthening of sea motions due to resonance phenomena.

In any case, there is evidence that the ehief leason of high waters in the Gulf of Venice must be sought in the passage of low pressure zones from 
the oper sea towarl the shore. The consequent swelling of the sen proceds along the sloped sea bottom, reaches the resonanee point (which may often hajuen in the High Ailriatic) where it is considerably intensified, sometines by several nuits over the static eflect, and this inerease amplitude learls uy to the coast. The efticieney of this mechanism is the stronger the less inclined is the sara bottom. Therefore, as a consecruenee of the sinking of the Western part of the Gulf of Veniec, to a particular extent in the delta area, the influence of this phenomenon on the high waters has been gradually increasing since $19 \overline{\mathrm{s}} \mathrm{l}$.

It is jroved that the II igh Adriatie (or parts of it.) may becouno extremely sensitive to stresses causes by pressure variations passing over the area, and that resonance plenomena may be produced by periodieal confluences as well as by linetie coincirenees. In anf event, the pressure varia. tions must by far be consinlered the most ellicient. cause of high waters in the Venetian lagoons.

Contrary to a widespread belief, the wind has ne determining weight in the formation of high waters; its intervention always constiutes a serondary cause.

The seareh of remedies to save Fenice is, of course, not within the scope of this writing. It is merely empluasized that the aggravation of the situation is linked, as above recalled, to furlher jossible sinkings of the underground layers. In a previous work I uentioned the similarly alaruing situation of Wiluington (Long Jeach) where the local base of the IS Navy - as a consequence of oil extractions from the nearby field of $\mathrm{I}$ ong Beach had subsicled to such an extent that in 1959 the wharfs had almost sunk helow sea level. The iutervention jurovidel by the introduction of large amounts of water into the subsoil of the entire area that had been allected, was not only alle to arvest the alarming phemomena, but sneceeded even in raising again the exterual surface to its original level referem to the sen. An acurately prepared action of underground pressurization of the I,agoon area should not $f_{a}$ il to achieve equally appreciable results for Venice.

\section{1. - "HIGI WATER" IN A BASIN OF CONSTANT CONFIGURATION.}

Thet us suppose that the morplological features of the Forthern Arintic Sea have remained unchanged fluring the past century. In this assumption - and apart from the astronomical tidle considered equally unclinnged as it has taken plaee during tle period in question which are the causes responsible for the ligh water observed in the Venetian lagoons? Obviously, the causes are to be seeked in the interactions occurring between the atmosphere and the hychosphere. From time to time my attention has been repestedly attracter by tilose phenomena. I have summer up their fundamental aspects in a study written in 1963 to which the reader is referred $\left({ }^{1}\right)$. 
Here I wish to molerline that water morements of exepptional size linve always been linked to resonance plenomena, arising during the propagation of more or less vast perturbations of the atmospheric pressure above the underlying water basin. The principal reasons of resonance are two: the propagation velocity of the atmospherio perturbation which tends towarl the velocity of free waves of the sea over which it passes, sund the bearing period of the pressure variation tending to coincide witl the period proper to a frec oscillation of the unalerlying basin.

The first reason explains, for instance, the variation of the water level in the Gulf of Trieste, and hence, the frec transversal oscillation of the High Adriatic Soa, I lave dealt with this subject repeatedly, so that it will be suffirient to recall the formula whicl summarizes the course of the phenomenon. When considering a canal which is closed at the extreme $x=0$ and extends indefinitely in the direetion of positive $x$ 's, the vertical movement is found to be subject to the relation

$$
\zeta=\frac{1}{1-v^{2} / c^{2}}\left\{F(t-x / v)-\frac{v}{c} F(t-x / c)\right\},
$$

where $v$ indicates the perturbation velocity, $c$ the volocity of lle free sea waves and $F$ any function of its arguments. In the case of the Gulf of Trieste the free oscillation takes place provided that the perturbing cause propagates from West to Enst, normal to the bottom of the Gulf $\left({ }^{2}\right)$.

Concerning the second condition of resonunce, it may be verifiol in many instances. Reducel to its simplest expression, the theory may be summarized in the following formula:

$$
\begin{aligned}
& \eta=\frac{k M}{\rho^{2}\left(m^{2}-1\right)}\left[\cos k(x-v t)-\frac{m}{\sin 2 h m}\{\sin k(l+v t) .\right. \\
& \cos h m(x-l)+\sin h:(l-v t) \cos k m(x \div l)\}],
\end{aligned}
$$

where $\eta$ represents the vertical movement, $c$ the propagation velocity of a long wave, o the density, $v$ the velocity of the perturbing action represented by

$$
M_{0}=M \cos k(x-v t),
$$


where $M$ is a generally small figure. The conditions at the limits are represented by an horizontal movement equal to zero for $x= \pm l$ with the length of the closed basin being $2 l$. Witl slight viniations the relation is valid for the open basin, too. Besiles, $h$ is the mean depth of the basin, and $m=v / c$.

In a first approximation we may consider

$$
c=1 / g h, \quad T_{i}=\frac{4 l}{i \sqrt{g h}} \text { lor } i=1,2, \ldots
$$

Contrary to what might appear, in this case $\eta$ does not tend towarl the infinite for $v=c$, whereas the resonance exists when $\sin 2 k m \rightarrow 0$. Il $s$ is an entire, and provided $2 \mathrm{klm}=8 \pi$, one has $\frac{T_{t}}{T_{s}}=\frac{s}{\imath}$, where $T_{b}$ is the period of the perturbing force $(*)$.

This elementary theory allowed me to explain the genesis of the internal waves of the Lake of Braciano ( $\left.{ }^{3}\right)$ and of the Jake of Garta (4), the formation of the free oscillations (uninodal, binolal...) in the Jake of Caldonazzo (5), as well as the sea storms in the Hirbour of Civitavecelia ( ${ }^{78}$ ).

There is no doubt that we have here one of the perturbing reasons bringing about the ligh water levels of the Venetian lagoons, every time the interaction between air and water is able to excite the free oseillations of the IIigh Adriatic or of the entire Alriatic Seat

How may be explained, then, the alarmingly increasing frecuency of ligh water in the Venetian lagoons and particularly at Venice? Supposing that morjohologically nothing las changed in the Adriatic, neither the bottom nor the water level, a change in the weather conditions must be presumed to which the said phenomena are connected. Although tlis hypothesis does not appear venturous - as will be seen - it is not my task to prove whetler it is valisl or not; who las more information available than $I$, has possibly something to say with regart to this.

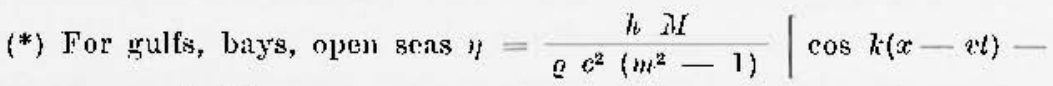
$\left.-\frac{m \sin k(l-v l)}{\sin 2 k m} \quad ; \cos k m(x+l)-\cos k m(x-l)_{i}^{\prime}\right)$

where $\eta=0$ for $x=0$ (month of open hasin, of lentrith $l$ ). Besides, $-\frac{T_{t}}{T_{s}}-\frac{s}{2 i-1}$. 
But has the IIigh Adriatic remained morphologically the same thuring the last decailes?

\section{2. - Morphologtcal chaxges of the High nimlatio Sed.}

Strictly speaking, no water basin, lowever large it may be, maintains its form unchanged: variations of level, alvancements of shores the to progressive sand deposits, withdrawals of shores due to erosions, changes of the bottom due to river thposits etc. are factors capable of modifying continuousiy the form of a basin and the water volume.

The changes of this kind wre negligible even over longer time freriods, as far as the Oceans are concemed, but not in cases of inlund seas. They may even take place rather rapilly with small, closed basins.

Among the inlant seas the Arliatic, and particularly the High Adriatic, is certainly among the most subjected to changes of this kind.

There is no doubt that still in the first centuries a.C. the Adriatic reached much farther than presently into the Po Valley und occupied all the line between Ravenna and $A q u i l e i a$, and that several centuries before Christ it extended to large parts of the territories including presently the area aroumil Fermar, the lower plains near Padova, the lowlands nount the Po Estuary and other Venetian regions. Ravema with its outstanding harbour in the Roman period, as well as Adria, the town which gave its nume to the entire sea bordering it, are today situated a long way inland.

At the same time a progressive subsidence of the underground took place, partly tue to a solidification of the soft and mulily surface layer, and partly to a slow flexion of the bottom of the Po-Adriatic ditch. This explains how such towns as Spina, braclea, Altiuo and others were gradually swallowed up and covered by mul and reedy marshes.

The piling up of debris and earth by the rivers and the subsidence of the underground were the chief reasons of so many radieal changes in the Venetian - Po estuary region in the course of centuries (c).

Generally, even today it is the earth which defents the sea: the slow work of the same forces which gradually built up the Po Valley continues indefatigably. The sand and clay, the mud carried by the rivers to their mouths and pusher on into the sea wentualy pile up on the bottom, fill in the deeper parts and contribute to the formation 
of a layer gently falling off toward the open sea and slowly raising the sea lottom.

Even if one leaves apart the variations of the shore, which are strongest in the area of the Po Delta, the bottom of the High Arliatic Sea is thus subjected to continuous changes due to the turbidity of the rivers. The latter reach the order of 370,000000 tons per yenr in the case of the Alige River, at Boara Pisani near its mouth, as deducted from the mean annual turbiometrical data for the 195i1963 period $\left({ }^{7}\right)$. If one considers the numerous rivers flowing into the High Arlriatic, the largest of wlich, but by far not all, are the Isonzo, the Tagliamento, the Livenza, the Piave, the Brenta, the Adige, the Po, the Reno... one is readily aware of the enormous amount of material whicl is continuously unloucted into this stretel of sea. The afflux takes sometimes gigantic proportions during floods and overflows of rivers near their mouths, and chiefly of the Po.

The tlumping of turbid material by means of rivers concerns without doubt, as far as the finer components are consilered, the entire Higl $A$ driatic Sea. Obviously, an exact appraisal of the clianges taking place on the bottom of the Higl Aslriatic in the course of time is not an easy matter. It would require dependable batliymetrical charts obtained through frequent and thorough measuring cimpaigns. Unfortunately, this requirement is met only to a very limited extent.

Anyway, the order of magnitude of major variations may be oltainel from comparisons of bathymetrical clarts executed after measurements made in diflerent periods. To this ellect, figure $T$ is referred to comparisons between developments of the sea bottom in three different directions, as expressed by batlymetrical charts of the perion $1867-1873\left(^{8}\right)$ and of the year $1896(1928)\left({ }^{9}\right)$. It will be noted that in all three cases examined the bottom showed deciderlly a raising tendency. This applies as well to comparisons in other directions which would be too lengtliy to report here $(*)$. Of course, the results are only of an indicative nature and roughly approximative, but they are sufficient to give evilence of a progressive, low rise of

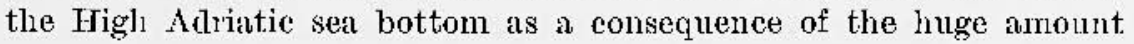

(*) No comparisous with more recent bathymetries have been makle since these were entered in charts of rather relued scales, and since the results are gathered in isobath lines rather than being registered point after point as in earlier times. The bathymetrical explorations recently marle for C.N.R. in the Iligh Adriatic $\left({ }^{10}\right)$ will be valuable for future comparisons. 
of nuterial of erosion carried forward from the Alps and the Appennine by the rivers flowing into it.

We shall revert to this subject.

It will be lielpful to cover now some hydrodinamieal aspects.

3. - OX FREE AND FOROED OSCILLATIONS OF A BASIX STHJECT TO TIDE.

\subsection{General.}

It is known that a water basin, either closed or open, may present two types of oseillations proper (or free) ones and forced ones. The period of proper oscillations depends on the configuration of the basin; the periorl of the forced oscillations coincides with that of the perturbing force and is therefore independent from the basin's geometrical features.

If $T$ is the kinetic energy of a meclanical system, made up by a certain amount of material points, with a finite number $n$ of degrees of freclom, whose situation may be defined by $n$ parametres $q_{1}, q_{n} \ldots q_{n}$, if $q_{r}^{\prime}=\frac{d q_{r}}{\bar{a} t}$ and if $U$ represents the potential energy due to the internal forces, the equations of Lagrange, conceming the motion of the system, will be:

$$
\frac{d}{d t} \cdot \frac{d T}{d q_{r}^{\prime}}-\frac{d T}{d t_{r}}+\frac{d U}{d q_{r}}=Q_{r} \quad(r=1,2, \ldots n)
$$

where $Q$ r represent the external forces.

The extention to the problems of the tides is obtained by replacing the finite sums by integrals.

Equations [1] are valid only for absolute motions. Considering the rotation of the Earth, a relative motion of the seas follows. If $q_{0}\left({ }^{*}\right)$ indicates the actual orientation of the system in the absolute space $\left(\frac{d T}{d q_{0}}=\frac{d U}{d q_{0}}=0\right)$, by the lack of external couples tending

$\left(^{*}\right)$ If one supposes three mobile axes invarially bound the solis earth and three fixed axes, and coinciding the axes $\approx$ in the two systems, qo will represent the angle of mobile axes with fixed axes; and the other coordinates $g_{r}$ indicate the relative position of the system referred to the molile axes. 
to vary the Eartll's rotation $\left(Q_{o}=0\right)$, the equation of Lagrange for the parameter $q_{0}$ is reduced to $\frac{d}{d t} \frac{d T}{d q_{o}^{\prime}}=0$, and hence $\frac{d T}{d q_{0}}=n_{a}$ where $p_{0}$ is a constant. Mrade

$$
H=T-U-p_{\circ} q_{\circ}^{\prime}
$$

one finds the equations of Lagrange becoming ( $\left.{ }^{11}\right)$

$$
\frac{d}{d t} \frac{d H}{d q_{r}^{\prime}}-\frac{d H}{i_{q_{r}}}=O_{r} \quad(r-1,2, \ldots w)
$$

The equations of Iagrange maintain, therefore, the same form when one considers the balance on the relative motion.

\subsection{Study of the free oscillations.}

When the external forces are zero $\left(Q_{r}=0\right)$, the equation of Lagrange for the parameter $q_{k}$ becomes

$$
\frac{d}{d t} \frac{d H}{d q_{k}^{\prime}}-\frac{d H}{d q_{k}}=0
$$

Here we have $n$ linear equations with constant coefficients.

We express the various elements of $H$ depending on the mechanical properties of the system. We have

$$
T=\sum \frac{m}{2}\left(x^{\prime 2}+y^{\prime 2}+z^{\prime 2}\right)+q_{o}^{\prime} \operatorname{Sm}\left(x y^{\prime}-y x^{\prime}\right)+q_{o}^{\prime 2} \sum-\frac{m}{2}\left(x^{2}+y^{2}\right),
$$

where $m$ represents the miss of a material point of coordinates $x$, $y, z$ referrerl to the free axes, and the apexes stand for derivalives agninst time. If $T^{\prime}$ expresses the half kinetic energy of the system in its relative motion, $\| I$ the angular momentum and $J$ the relative moment of inertia, we may write

$$
T=T^{\prime}+q_{o}^{\prime} M+q_{o}^{\prime 2} \frac{J}{2} .
$$

Furthermore

$$
p_{o}=\frac{d T}{a q_{o}^{\prime}}=M+q_{0}^{\prime} J
$$


so that

$$
H=T^{\prime}-U-\frac{1}{2} \frac{1}{2}\left(p_{0}-M\right)^{2}
$$

Considering the smallness of coordinates and of relocities, so that all the terms above the 2 nd slegree may be neglecterl, plotting against: $q^{\prime}$, we have

$$
H_{2}=T^{\prime}-\frac{M_{2}}{2 \cdot \bar{J}}: \Pi_{1}=\frac{p_{0} M}{J}{ }^{\cdots} ; \Pi_{0}=-U-\frac{p_{0}:}{2 J}
$$

Therefore, by emphasizing the various parts of $H$, equations [3] becoune

$$
\frac{d}{d t} \frac{d \Pi_{2}}{d q_{k}{ }^{\prime}}: \frac{d}{d l} \frac{d H_{1}}{d q_{k}^{\prime}}-\frac{d H_{1}}{d q_{k}}-\frac{d H_{0}}{d q_{k}}=0
$$

Since $\Pi_{2}$ is a polynomial of the 2 nd tegree in $q, \frac{d \Pi_{2}}{\vec{u}_{\tilde{q}} k^{\prime}}$ will assume the form $\frac{d H_{0}}{d q_{k} k^{\prime}}=\sum a_{r k^{\prime \prime}} q_{r^{\prime}}$, from which $a_{r k^{\prime \prime}}=\frac{d^{\prime 2} H_{2}}{d q_{r}^{\prime} d q_{k}{ }^{\prime}}$ where $a_{r k}$ ale constants.

It is prover (Poincare, l.c., ]. 12) that, since $\Pi_{1}$ is a polynomial of the 1st degree in $q$ and in $q^{\prime}$, after

$$
a_{r k^{\prime}}=\frac{d^{2} H_{1}}{d q_{r} d q_{k}^{\prime}}-\frac{d^{2} H_{1}}{d q_{r^{\prime}}^{\prime} d q_{k}}
$$

it follows:

$$
-\frac{d}{d t} \cdot \frac{d H_{1}}{d q_{k}^{\prime}}-\frac{d \Pi_{1}}{d q_{k}}=\sum a_{r k}^{\prime} q^{\prime}
$$

While, being $\Pi_{0}$ a polyuomial of the 2 nd degree in $q$, after

$$
a_{r k}=-\frac{d^{\mathrm{s}} \Pi_{2}}{d q_{r} d \bar{q}_{k}}
$$

then

$$
-\frac{d H_{o}}{d q_{1}}=\sum a_{r k} q_{r} .
$$


Therefore, the equations of legrange [4] take the form

$$
\sum\left(a_{r k}^{\prime \prime} q_{r}^{\prime \prime}+a_{r k}^{\prime} q_{r}^{\prime}+a_{r k} q_{r}\right)=0 .
$$

We have $n$ linear equations with constant coeflicients, whose system may be integrated by putting

$$
q_{r}=\alpha_{r} e^{i t}
$$

where $\lambda$ and $a_{r}$ are cletermined so that the equations are satisfied. By substitution the latter bccome then

$$
\sum \alpha_{r}\left(a_{r k^{\prime \prime}} \lambda^{\prime \prime}+a_{r k^{\prime}} \lambda+a_{r k}\right)=0
$$

or, after

$$
\begin{gathered}
C_{r k}=a_{r k}^{\prime \prime} \lambda^{2}+a_{r k^{\prime}} \lambda+a_{r k}, \\
\sum \alpha_{r} C_{r k}=0
\end{gathered}
$$

We have $n$ lomogeneous linear equations in $n+1$ unknown values, $\alpha_{1}, \alpha_{2} \ldots \alpha_{n}, \lambda$. The problem is possible if the determinant of the said equations is zero:

$$
\Delta(\lambda)=0
$$

On the other hand, it is proved that $\Delta(\lambda)=\Delta(-\lambda)$. Therefore, equation [6] has equal roots two by two, of opposite sign.

In the case of stable equilibrium, of interest to us, these roots (Poincaré, l.c., p. 14) are purely imaginary:

$$
\lambda-i \mu
$$

being $\mu$ real. Therefore, there are $2 n$ particular solutions which sutisfy the equations of Lagrange and correspond to the $2 n$ roots of equation [6]. They constitute the harmonic solutions its own of the system, periodical functions of time, proportional to an imaginary exponential.

If

$$
\alpha_{r}=\varrho_{r} e^{i \omega_{r}}
$$


each of the system's complex harmonic natural oscillations will be given by the $n$ values

$$
q_{r}=\varrho_{r} e^{i\left(\mu t+\omega_{r}\right)}
$$

of parameteres $q$.

Since the differential equations are linear and have real coefficients, the real part and the imaginary part of the complex solutions will satisfy the problem separately. Thus, to each complex solution correspond two real solutions

$$
\begin{aligned}
& q_{r}=\varrho_{r} \cos \left(\mu t+\omega_{r}\right) \\
& q_{r}=\varrho_{r} \sin \left(\mu t+\omega_{r}\right) .
\end{aligned}
$$

These are the natural-free-harmonic real oscillations of the system. By combining the $2 n$ particular solutions of the dillerential equations we obtain the problem's general solution.

The period of a free oscillation, corresponding to the value of $\mu$, is given by $\frac{2 \pi}{\mu}=\frac{2 \pi}{\lambda} i$. The equation in $\hat{\lambda}$ defines, therefore, the periods of the free oscillations.

We are determining now $Q_{r}$ and $\omega_{r}$, viz. $\alpha_{r}$.

If we indicate by $D_{r k}$ the minors of the determinant $\Delta(\lambda)$, we have

$$
\Delta=\Sigma C_{r k} D_{r k}
$$

From the theory of homogeneous linear equations follows

$$
\frac{\alpha_{1}}{D_{1 k}}=\frac{\alpha_{2}}{D_{2 k}}=\ldots=\frac{a_{n}}{D_{n k}} .
$$

The minors are complex quantities completely determined, once $\lambda$ is known. This allows to determine $a_{r}$.

\subsection{Study of the foreed oscillations.}

With the action of non zero external forces, the term $Q_{r}$ of the Lagrange equation, concerning the parameter $q_{r}$, takes the form

$$
Q_{r}=\sum K_{r H} e^{\lambda_{H h} t}
$$

where the exponential factors are hamonic functions of time.

We are now considering the complex components of the perturbing force. Each of them will bring about an isochronal forced oscillation with 
the sume periof; and when all components at the same time will act the resulting oscillation will be the sum of the oscillations caused by each of them, due to the principle of ovorlapping of the small movements.

So we examine only one of them. We put

$$
Q_{r}=K_{r} e^{\lambda t}
$$

To this perturbing force corresponts a forcesl oscillation

$$
q_{r}=\varepsilon_{r} e^{\lambda t}
$$

In that case 1.lo Isigrange equations become

$$
\frac{d}{d t} \frac{d I I}{d q_{k^{\prime}}}-\frac{d I I}{d q_{k}}=K_{k} e^{\lambda t} \quad(k=1,2, \ldots n)
$$

By distinguishing the three parts of $I I$ alreaty consideret in the prefious palagraph, equations [8] become

$$
\sum\left(u_{r} k^{\prime \prime} q_{r}^{\prime \prime}+a_{r k^{\prime}} q_{r}^{\prime}+a_{r k} q_{r}\right)=K_{k} e^{2,},
$$

with $k$ and $r$ varying from 1 l.o $n$.

For equation [7], and by recalling [5] we have the set of equations

$$
\sum \varepsilon_{r} C_{r k}=K_{s}
$$

Since $\lambda$ is given, the $C_{r k}$ are known constants.

Each of these rquations inchules the $n$ muknown falues $\varepsilon_{r} ; n$ is the number of the equations. Lilie eqs. [j], they are of ble first degree, no more homogeneous but with a second member. They will be solved, therefore, by the Kramer methol. In exch solution at renominator shall appear the teterminand with $C_{r k}$ eorfficients of nuknown terms formed, whilst at numerator shall be the same determinant where $C_{r_{1}}, C_{r_{2}} \ldots C_{r n}$ are replaced $b F K_{1}, K_{2}, \ldots K_{n}$, respectively [that is $\left.\sum K_{h} D_{r h}(\lambda)\right]$.

$A$ particular solution of the problem of foreal oscillations is given, therrofore, by the $n$ values

$$
\varepsilon_{r}=\frac{\sum K_{h} D_{r h}(\lambda)}{\Delta(\hat{\lambda})}
$$




\subsection{Comparison between forced and free oscillations.}

The quantity $\varepsilon_{r}$ is a rational function which ean be divided into simple elements.

If we iudicate by $\lambda_{f}$ one of the $2 n$ roots of equation $\Delta(\lambda)=0$, we lave seen that the corresponding proper oscillation is given by the values of parametres

$$
q_{r s}=\alpha_{r j} e^{j_{j} t}
$$

where $j$ varies from 1 to $2 n$ and $r$ from 1 to $n$.

These $q$-vilues are solutions of the homogeneous diflerential equations where $q_{r}=\varepsilon_{r} e^{h l}$ is a particular solution of the same equations with a second member.

The problem of the fored oscillations will therefore be solved by adding to the purticular solution any solution of the lomogeneous equations, in other worls an its own solution. The roots of the denominator, $\lambda=\lambda_{s}$, are the ones which define the periods of free oscillations of the system; to each of such roots corresponds a term $\frac{\sum K_{h} D_{r h}\left(\lambda_{s}\right)}{\left(\lambda-\lambda_{s}\right) \Delta^{\prime}\left(\lambda_{3}\right)}$ $(h=1,2, \ldots n)$. By summing with respect to $j(j=1,2 \ldots 2 n)$ we get

$$
\varepsilon_{r}=\sum^{-} \frac{\sum K_{h} D_{r h}\left(\lambda_{1}\right)}{\left(\lambda-\lambda_{, j}\right) \Delta^{\prime}\left(\lambda_{1}\right)} .
$$

As the conjugated imaginary solutions are $s_{r j}=\beta_{r j} e^{-\lambda_{j i} i}$, it is proved that (Poincare, l.c. pages $15-16-20)$ the ratio $\frac{D_{r h}\left(\lambda_{j}\right)}{a_{r j} \beta_{h j}}$ is independent from $r$ and $h$, so that we may write

which leakls to

$$
\frac{J_{r h}}{a_{r j}} \frac{\left(\lambda_{j}\right)}{\beta_{h j}}=\mu_{j} \Delta^{\prime}\left(\lambda_{j}\right)
$$

$$
\varepsilon_{r}-\sum \sum \frac{K_{h} \mu, \alpha_{r j} \beta_{h j}}{\lambda-\lambda_{j}},
$$

from which the expressions of $q_{r}$ parthmetres follow. By writing $q_{r}^{\circ}$ to inticate that this solution is a particular one of the nonhomogeneous equations, we get:

$$
q_{r^{\circ}}=\sum_{j=1}^{i=2 n}\left(\frac{a_{r j} e^{\lambda t}}{\lambda-\lambda_{j}} \sum_{i}^{n} K_{n} \mu_{j} \beta_{h j}\right) .
$$


$\lambda$ and $K_{n}$ are given constants, since referred to the linown perturbing force; $\lambda_{j}, \mu_{j}, \alpha_{r}$ and $\beta_{h s}$ are as well constants referred to the free oscillation, the preriorl of which is tefines by the root $\lambda$, of equation [6]. It is proves (Poincaré, l.e., 1, 26) that $2 \mu_{\mathrm{s}}=-\lambda_{k}$, so that, after

$$
T_{0}=\sum \kappa_{h} \beta_{h j},
$$

equation [9] may be written

$$
q_{r^{0}}=-\frac{1}{2} \sum T_{0} \alpha_{r j} \frac{\lambda_{i}}{\lambda_{r}-\lambda_{i j}} e^{\lambda t} .
$$

lixcept one coefficient which does not depend on $j$, the general term of $q^{\circ}$ will be $\alpha_{r j} e^{2}$. Hivery term corresponds to a harmonic foreed oscillation. By compring this oscillation with the corresponfling free oscillation, we see that $\alpha_{r j}$ is the sime for both oscillations, being the exponential coeffieient $e^{A t}$ for the former and $e^{\lambda, t}$ for the latter.

Eacl forced oseillation luas thus, in its various points, the same phase difference as the corresponding harmonic natural oseillation and a proportional ampliture, but its period is tifierent from it, namely that of the perturbing force.

A very interesting fact is to be underlined. Let us suppose that $\lambda$ is very near one of the values $\lambda_{j}$ pertaining to the free oscillations.

The corrosponding term in the expression of $q_{r}$ becomes then prodominant, and the observed foreed oscillation differs very little with regard to the period, the ratio of amplitudes and the phase difference in various points of one of the system's harmonic fres oscillations: and this tendency to coincide is accompanied by a magnification of the resulting motion. This is the case of resonanee which takes place in eertain sea basins with strong tide netion, such as in the Fundy Bay and other areas, approaching to a proper homonie oscillation of the basins.

To which extent does this phenomenon apply to the High Adriatic Sea? And, should it occur even in limited proprortions, which is its present tendency? Do the morphologieal variations contribute to accentuate its eflects?

4. - ON FIRE OSCILAATIONS OF THE ADRIATIC SEA AND OF PARTS OF IT.

It is several centuries that the tirles of the Arliatic have been observed and studied. Giusepre Toaldo deals with subject at large 
in a publication of $1781 .\left({ }^{12}\right)$, and particularly in article VITI: "Essay on the tide of the Arratic GuIf" in which he distinguishes the diumaI tisle, the "mestrual" (the monthyy) tide and the anmual tide. But: more accurate research was ilone toward the end of the last century and in the begimning of the present (13-19).

It is the merit of von Kesslitz to have proved for the first time the existence of a natural oscillation of the Aritiatic Sea whose period he estimated to be about 23 hours. He considered this oscillation the uninodal of the entire Ailriatic, the uninode being situated where the Adriatic is linked to the Meditermanean (which was eflectively mover by von Sterneck). Also Defant $\left({ }^{20}\right)$ aceepted von Kesslitz's conclusions and calculated for the period of the Alriatic, consislered as a gulf of the Mediterranean, a value of 22.4 hours, near which reached by von Kesslitz from his observations.

Von Kesslitz had also observed a stationary wave of a period of about 12 hours. This oscillation, very near the semidiumal tide, was initially interpreted in a different way. Defant considered it as a fundamental oscillation for the Arliatie which he conceived like a Iake, and hence with two troughs at the extreme North and South (Channel of Otranto). Others attributed it only to the oscillation of the open Northern Adriatic basin, for which von Sterneck indicated a. period of 12 hours, Oddone one of 11.5 hours (21).

IIow do the free oscillations of the Adriatic originate?

The influence of atmospheric pressure variations on closed basins is not limited - as could be already seen, by the way - to static action; very often it induces dynamic phenomena and gives rise to sometimes considerable level differences. The wind, too, has an influence on the sea level. In the Adriatic, as is known, the Sciroceo wind pushes the water toward the Nortlern coasts and causes rises. The Bork, which blows from ExE, brings about the opposite affect.

Francesco Tercelli, who on different oceasions liad to look into the effect of the weather perturbations on the sea level, pointed out in a study rated $1922\left({ }^{22}\right)$, in a diagram of a year's recordings of the Trieste tide gange, the existence of periodical waves having a period of about 11 hours and others with a period of about 22 hours, similarly to what von Kesslitz had previously ascertained for the ports of Pola (18) and Ragusa (19). By applying to the recorded eurve lis method of period analysis, rereelli found - as he writes in the said study - periods of approximately 22.2 hours and 11 hours for the two 
above mentioned waves. Ton Kesslitz's approximate values were thus corrected by Vercelli of about one hour (less).

Concerning the uninodals, an attempt make by odalone will a small model of the Adriatic, led to values which are probably excessive (1).

13: applying Vercelli's cymoanalysis, Polli examined four sections of tirle anuge curves recombd in Trieste on January 29, February 2, 1948, June 3-6, 1948, Oetober 18-22, 1949 and April 15-17, 1950, respectively (2a). In the examines cases Polli foumd values of 21.4 $( \pm 0.7), 21.2,21.5$ and 21.0 hours for the uninodal of the entire sea, and 1.2.2 hours for the semidiumal wave, thus returning 10 ron Fesslitz's value. A remark sliould be male, lowever, about the minotal. In renlity, the values given are mean values. In figure 1 of Polli's work (l.e, pare 70) the first complete wave shows a period of 20.5 howrs, the second one of 23.7 hours, the thiril one of 21.0 liours, the fiftl one of 21.9 hours, etc. From fig. 2 (l.e., page 71) it is lard to deduct trustwortly values. There are clearly time-indeponilent oseillations, having a pseudo-period of about 28 hours, another wilh one of 21.4 lours. 1'ig. 3 (l.c., page $\tau t$ ) slows as well that the first oscillation with a porior of 23.9 hours is separated from the next which has a small amplitule. The average of 21.5 hours, taken from Polli's work, sliould be viewed, therefore, only as indicative. I slanll revert to it later.

The value of 21 loums, calculated by $\mathrm{C}$. Bajc ${ }^{(24)}$, cammot be considered very exact, as the anthor almits himself, for having been deslucted from too daring schemes, which cannot take into account the elementary consequences of the basin form on the periorl of its free oscillations.

Only a differential methor which gives due consideration to the continuous variations of the basin's form is able to leal to acceptable approximations. This is obvious to anyborly who has rollected experience in the study of the water-surface oscillations. Therefore, in my opinion the most trustwortly values for the natural periods of the Arliatic Sea are those collected by Kasumovic $\left({ }^{25}\right)$. He extenter Chrystal's method to some fourty cross sections which led him to a normal curve, similar to the one I found in dite time for the Isake of Levico, and then to the same sysiem of operative formulas (26). The fundamental oseillation of the Arlriatic Sea as a gulf open toward the Mexliterranean thins proves to have the value of 22.11 hours (methor of Clrystal) and 23.16 lonus (method of Goliberg) which ipronclies 
the value of 23.34 loturs as calculated by Defant. The avelage of observations led Kasumovic to the value of $22.7 \pm 0.8$ hours, which fairly agrees with the ualculaten values.

With the Cluystal methor applied to the stretch of sea between the Venetian coasts and the line running from Mit. Gaugano to the Islauls of Pelagosa, Iagosta, Curzola, considered as a lake, Fasumovic obtains for the natural oseillation of abont 12 lowis the ralue of 11.31 lours, while the arorage of observations leads lim to $11.76 \pm 0.3$ lours. The author's lyyothesis is supported by the tide gange recordings slowing opposite troughs at Fenice and at Fieste, with a nodal line rumning from Aneona to the Island of Pago. Kasumovic rexches this conclusion after having shown that Tefant's hypothesis is erroneous which made tlo oscillation of about 12 hours the uninodal of the entire Adriatic oscillating like a lake.

But let us revert for an instance to the uninodal natural oscillation of the Adriatic. As I said above, in my opinion its poriod is the one calculated by Kasumovic, tlat is at least 22 hours. If it is, as could be prover, the fundmmental of the Adriatic as a gulf open towarl the central Mediterranean, the laws of hydrodynamics warmat the possibility of being realized since its nolal line comes out over a basin with natural oscillations of a longer period. That this is its origin is also proved, besiles, by the recordings where tle waves appear

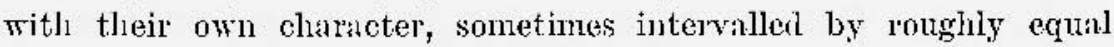
wave lengtl 1 s (Vorcelli, l.e., table IV), sometimes partially overlapped (Polli, l.e., page 70), sometimes separated by more or less long intervals (Polli, l.e., page 71) or even isolated (Polli, l.e., page 74). And this explains itself by taking into account that these waves are oscillations of a basin whicl is open above another, muels larger basin. In that way, when the perturbing cause is acting, the oscillation refurning from the gulf base, proceets beyond the norle as a progressive wave and runs out $t_{1}$ en in one period. The rise of a new oscillation presupposes the continuity of the originating cause or its reapearance which may be in advance or after an entire periorl (27-31). Any methorl of period analysis requires the continuity of the investigaterl wave train. If it is lacking, the data will have to be averaged with inevitable "lengthenings" and "shortenings", so 11ut the restits are frequently far from reality. For these reasons I think that Kasumovic's menn value of observations ( $22.7 \pm 0.8$ hours) gathered with other methods, deserves more trust.

Owing to the way in which it happens, also the wave of about 12 
lours is subject to quick attenuations as soon an the perturbing cause fails to appear, althougl to a lesser degree than the wave of about 22 hours.

Even more limitated parts of the Adriatic are capable of sizeable natural oscillations (figs. 1-6). Thus, when a weather perturbation moves from West to Wast and crosses the IIigl Miliatic, the Gulf of Trieste becomes subject to a free oscillation at a rhythm of about 3.5 hours, as I coult prove in $193 \pi$. When the energy of the perturbing force is sufficient, the level variation of the Gulf of Trieste changes into a natural oscillation of the Gulf of Venice as a closs oscillation of the Figh Adriatic ( $\left.{ }^{2}\right)$. It always takes part in the big weather events. As the first maximum is reached at Trieste, some 3.5-1 hours later the Venice tisle is overlapped by an increase varying between 15 and $40 \mathrm{cms}$. Tere one gets aware of a possibility of forecasting, and be it only partially, the high water in Venise (figs. 1, 4-6).

\section{5. - IEFFECTS OF DEPTI ON TIIF AMPLITUDE OF FREE OR FORCED OSCII- JATIONS OF A BASIN.}

After laving examined the periouls of the chief free osciliations of the Adriatic, we are now trying to fix the behaviour of the latter in the Gulf of Venice, that is in the part in which we are interester. To this eni we have to remember some aspects of lyydrodynamics.

According to the theory and to the observation of the natural oscillations of a water basin - provideal the other conditions are equal - the amplitude of oscillations is always largest in the spots of lesser depth, and the diversity grows with the increase of the depth difference at the two extremes (in the case of closed basins). This explains why, for instance, the uninotal of the Lake of Caldonazzo las an amplitude twice as large in the extreme North (San Cristoforo) than in the South (Lido of Caldonazzo) $\left({ }^{30,5}\right)$, why the uninodal of the Jake of Levico is four times as large in the Nortl than in the South $\left({ }^{26,30}\right)$ and why the amplitude in the Lake of Albano is abont five times as large in the East than in the extreme West where the depth is considerable ( $\left.{ }^{31}\right)$. This effect becomes most spectacular with artificial basins created by damming the $A$ pine valleys. Therefore the fundamental free oscillations next to the clam have always consicleably lower amplitudes than the ones observed at the end more upstream of the dam. 
Let us consider the case of the Adriatic. This sea may be roughly considered as laving been built up by two consecutive concavities, one of Iimited depth in the North (exeept the meso-alriatio ditch of little extension) and one of over $1,000 \mathrm{~m}$ depth in the South (lig. 8-9). The boundary-line between the two basins may be seen roughly the jointing-line Vieste-Ragusa, as around this line the son doptli falls almost abruptly from 200 to 1,200 metres (fig. 8).

That being stated, we are now considering the free oscillations of $u$ basin made up by two such concavities. In orrler to block out the problem we imagine a channel limited by two vertical walls $x=-b$, $x=+b^{\prime}$ and with a step-shaped in $x=0$. The depths in the two sections are indicated by $h$ and $h$ (lig. 10 ); they are considered rather small in comparison to the wavelengtlis.

We have to find a function $\varphi$ of $x, y$ which satisfies the condition (Poincuré, l.c., page 90)

$$
\frac{d^{2} \varphi}{d t^{2}}=y^{2} \Delta_{2} \varphi
$$

where $\Delta_{2}$ is the Laplacian of $\varphi$.

Since $\varphi$ is always yroportional to eht, where $\lambda$ expresses the wavepulsation, we may wite for the free oscillations

$$
\lambda^{2} \varphi=g \Delta_{2} \varphi
$$

Referring to the basin's deep part, we put.

$$
\varphi=A e^{\lambda t} \cos i \lambda a(x+b)
$$

and will get

$$
\frac{d \varphi}{d x}=-i \lambda a A e^{\lambda t} \sin i \lambda a(x+b) ; \frac{d^{2} \varphi}{d x^{2}}=\lambda^{2} \alpha^{2} \varphi ; \frac{d \varphi}{d y}=0 ; \frac{d^{2} \varphi}{d y^{2}}=0 .
$$

The condition $-\frac{d \varphi}{d x}=0$ for $x=-b$ is satisfierl. Besides, $\Delta_{2} \varphi=\lambda^{2} \alpha^{2} \phi$.

From equation [11] we get therefore

$$
\alpha=\frac{1}{\sqrt{g / h}} .
$$


For the less deep part, provided

$$
\phi=A^{\prime} e^{\lambda t} \cos i \lambda \alpha^{\prime}\left(x-b^{\prime}\right)
$$

after the boundary-conditions lave been fulfilled, we get also

$$
u^{\prime}=\frac{1}{\sqrt{g} h_{h}^{\prime}} .
$$

$\varphi$ as a continnous function takes equal values at the one side of $x=0$ and the otlıer, lrom which follows

$$
A \cos i \lambda \alpha b=A^{\prime} \cos i \lambda \alpha^{\prime} b^{\prime} \text {. }
$$

Being $x=0$, also $\bar{n} \frac{d \varphi}{d x}$ must be continuous $\left(h \frac{d \varphi}{d \dot{x}}\right)_{x=0}=\left(h^{\prime} \frac{d \varphi}{d x}\right)_{x=0}$

It follows $h \alpha A \sin i \lambda a b=-h^{\prime} \alpha^{\prime} A^{\prime} \sin i \lambda \alpha^{\prime} b^{\prime}$.

Dividing equations [1t], [15] by members one obtains

$$
a h \text { tang } i \lambda a b=-a^{\prime} h^{\prime} \operatorname{tang} i \lambda a^{\prime} b^{\prime} \text {. }
$$

Therefore, for $h^{\prime}<h$ is $a^{\prime} \neq \alpha$; and since for [12] and [13]

$$
\frac{a^{\prime} h^{\prime}}{a h}=1 \frac{\overline{h^{\prime}}}{h^{\prime}}
$$

it follows

$$
a^{\prime} h^{\prime}<\alpha h \text {. }
$$

In absolute value, we lave therefore

$$
\mid \text { tang } i \lambda \alpha b|<| \text { tang } i \lambda \alpha^{\prime} b^{\prime} \mid \text {. }
$$

Since $\lambda$ is imaginary (page 86), the arguments $i \hat{\lambda} a b$ and $i \lambda \alpha^{\prime} b^{\prime}$ are real; therefore, since the cosines decrease as the tangents increase, we have in absolute value

$$
|\cos i \lambda \alpha b|>\left|\cos i \lambda \alpha^{\prime} b^{\prime}\right|
$$

from wlich follows for eq. [14]

$$
A^{\prime}>A
$$


which means that the amplitude of the free wave results higher in the less deep part of the bosin.

We are now examining the propagation of a forced wave along the above mentioned channel. Is previously, we assume a depth $h$ for $x<0$ and one $h^{\prime}$ for $x>0$, so that for $x=0$ the depth turus abruptly from $h$ to $h^{\prime}$ (fig. 10). In order to approach the problem of tides, the said deptlis are considered infinitely small in comparison to the wave lengtih.

In the section $x<0$ we are considering a wave propagating toward the positive $x$ 's. Ititting against the step-shnped $x=0$, this wave suflers a partial reflection. In the first scetion the movement depends therefore on a function

$$
p=F(t-a x)+F_{1}(t+a x)
$$

Since the equation of the motion is

$$
\frac{d^{2} p}{d t^{2}}=g h \frac{d-m}{d x^{2}}
$$

we'll lave in $\varphi$

$$
\alpha=\frac{1}{1 / g h} .
$$

In the section beyond the $x=0$ step-slaped, we have the propugation of the residual wave

with

$$
p=F_{2}\left(t-a^{\prime} x\right)
$$

$$
\alpha^{\prime}=\frac{1}{\sqrt{g h^{\prime}}} .
$$

Through the continuity, in $x=0$ it must be

$$
F+F_{1}=F_{0}
$$

Pesiles, it is proved that for $x=0$, also $h \frac{d \varphi}{\bar{d} x}$ must be continuons, so that we'll lave on both sides of the step-shaped

$$
\alpha h\left[F^{\prime \prime}(t)-F_{1}^{\prime}(t)\right]=a h^{\prime} F_{2}^{\prime}(t),
$$


where $F^{\prime}$ represents the derivative of $F$ with respect to $x$. By integrating one obtains

$$
\alpha h_{h}\left(F-F_{1}\right)=\alpha^{\prime} h^{\prime} F_{g} .
$$

Combined with equation [18], this relation allows to determine $F_{1}$ and $F_{2}$, once $F$ has been assigned. On the otler hand, from equations [16] and [17], it is deducted

$$
\frac{a^{\prime} h^{\prime}}{a h}=1 \frac{h^{\prime}}{h} .
$$

Therefore, for $h^{\prime}<h$, from equation [19] follows $F^{\prime}-F_{1}<F_{2}$, and therefore, for equation [18]

$$
F_{2}>F .
$$

Thus, the movement takes place with an higher amplitude in the less decp part of the channel.

At last we are considering a progressive wave propagating along the same clatunel. For [11], the equation of wave proplagation may be written

$$
g h \frac{d^{2} \varphi}{d x^{2}}=\lambda+\varphi
$$

where, in the decper section $($ ieptil $1=h)$,

$$
\varphi=B e^{i \mu x+\lambda t}+B^{\prime} e^{-i \mu x+\lambda t},
$$

while beyond the $x=0$ step-shaped leading to the second section, on the prolongation to the first section (in our case represented by the Adriatic ditcl 1 which extends into the High Adriatio)

$$
\varphi=B^{\prime \prime} e^{i \mu^{\prime} x+\lambda t} .
$$

Moreover, from [21] one lhas

$$
\frac{d \varphi}{d x}=i \mu\left(B e^{i \mu x}-B^{\prime} e^{-i \mu x}\right) e^{\lambda t} ; \frac{d^{2} \varphi}{d x^{2}}=-\mu^{2} \varphi .
$$

from [20] one gets then

$$
-\frac{\mu^{2}}{\lambda^{2}}=\frac{1}{g h} .
$$


From $[2 * 2]$ results

$$
\frac{d \varphi}{d x}=i \mu^{\prime} B^{\prime \prime} e^{i \mu^{\prime} x+\lambda t} \quad ; \quad \frac{d^{2} \varphi}{a x-}=-\mu^{\prime 2} B^{\prime \prime} e^{i \mu^{i} x+\lambda i}
$$

and therefore, for [20]

$$
-\frac{\mu^{\prime 2}}{\eta^{2}}=\frac{1}{w h^{\prime}}
$$

so that

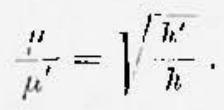

The first continuity-condition requires that [21] and [2\%] become equal for $x=0$; from which

$$
B+B^{\prime}=B^{\prime \prime}
$$

The second continuity-condition, in correspondence to the stepshaped $(x=0)$ learls to the equality

$$
h \frac{d \varphi}{a x}=h^{\prime} \frac{d \varphi}{a x}
$$

from [23] and [24] it therefore results

$$
\frac{\mu}{\mu^{\prime}} h\left(B-B^{\prime}\right)=h^{\prime} B^{\prime \prime}
$$

whence for $[25]$ and $[26]$

$$
2 B=B^{\prime \prime}\left(1+i \frac{\overline{h^{\prime}}}{h}\right)
$$

and, at last,

$$
B^{\prime \prime}=\frac{2 B}{1+\sqrt{\frac{h^{\prime}}{h}}}
$$

Therefore, for $h^{\prime}<h$ is $B^{\prime \prime}>B$. 
Consequentely the wave propagating in the seation of lesser depth has an higher amplitude then the one acting in the deoper section.

In conchusion: A system of long waves, in whichever way it propagates towarl the high Adriatic, reaches the Venetian coasts with a lirger amplitude than that with which it had run though the southern Acliatic.

6. - ON THF RESONANCF EFFFCT IN $A$ " HIGH WATER 》.

We are now considering another canse of dynamic clanges of the sea level, in connection with a variation of atmospheric pressure.

The Japunese H. Yommda, Y. Okabe and $\mathrm{H}$. Fumazawa proved ( ${ }^{32}$ ) that when a liquid intumescence - after a weather perturbation of invariable intensity advancing at constant velocity on the water surface - rises along an inclined bed and approaches the sliore, the high of the wave is all the higher the smallev is the slope of the bottom: the sudden increase takes place when the pressure variation passes over the resonance point, which had been defined with respect to the water depth.

If $P=P(X)$, where $X=x-V t$, expresses the intensity of the atmospheric pressure perturbation acting on the water surface on which it propagates at $V$-velocily ( $x$ delining, with $y=0$, the mean position of the liquid surface), one has

$$
h(\infty)=h_{o}\left(1-\lambda \operatorname{tangl}_{1} \frac{x}{L_{2}}\right),
$$

where $h_{0}$ inclicates the deptl in the point $s=0, \lambda$ is a constant, and $L_{2}$ the lengtil of the area sloping down.

It is proved that the wave-resonance originated by the passage of the perturbation sets in exactly at the $h_{0}$ depth, so that we get

$$
\bar{g} \overline{h_{0}}=V
$$

As the extension $2 L_{1}$ of the perturbation $\left(-L_{1}<X<L_{1}\right)$ increases, we have obviously a growth of the area hit by the heavy-sea; and the more $L_{2}$ increases, the less inclined is the bottom slope between two fixed depths $h_{1}$ and $h_{2}$ ( $h_{1}$ offsliore, $h_{2}$ near the coast). 
The surace and the bottom of the water are represented respectively by

$$
y=\eta(x, t) \text { and } y=-h(x)
$$

If $u$ is the lorizontal component of the liquid velocity, the following diflerential equations lave to be satisfied ( $\left.{ }^{33}\right)$ :

$$
\begin{aligned}
& \frac{\partial u}{\partial t}+u \frac{\partial u}{\partial x}=-g \frac{\partial}{\partial x}(\eta+P) \\
& \frac{\partial \eta}{\partial t}=-\frac{\partial}{\partial x}[u(h+\eta)]
\end{aligned}
$$

After fixing the $P$ - variation field

$y=-P_{0}\left\{1+\cos \left(\pi \frac{x-\frac{Y}{L_{1}}}{L_{1}}\right)\right\}$ for $\frac{x-\mathrm{T}^{\prime} t}{L_{1}} \leqslant 1$, (otherwise $y=0$ )

the authors effect a series of calculations witl the following starting data.

$$
\begin{aligned}
& P_{o}=0.10 \mathrm{~m}, L_{\mathrm{t}}=10 \mathrm{~km}, V=15.3362 \mathrm{~m} / \mathrm{sec} \\
& h_{o}=24 \mathrm{~m}, h_{1}=h_{o}(1+\lambda)=40 \mathrm{~m}, h_{2}=h_{o}(1-\lambda)=8 \mathrm{~m}
\end{aligned}
$$

where $\lambda=2 / 3$. Since $g=9.80 \mathrm{~m} / \mathrm{sec}^{2}$, one has

$$
\frac{V^{2}}{g h_{o}}=1.00, \frac{V^{2}}{g h_{1}}=0.60, \frac{V^{2}}{g h_{2}}=3.00 .
$$

The results are summarized in two tables and two figures. We are interested here to present the figure which gives the variation of $\eta$, that is of the surface lifting, in $L_{1}$ as $h$ varies (fig. 11). One notes the considerable ellect on the amplitule of the wavy motion

$$
m=V /\left(g h_{1}\right)^{1 / 2}=\left(h_{o} / h_{1}\right)^{1 / 2}
$$


$m->1$ for both falling and rising values: the ligh water accompanying the low pressure increases as $m \rightarrow 1$, anrl, after passing over $m=1$, constitutes the free wave behind the low pressure: it tends to swell as it moves ap the sloped bottom, and it increases all the more the ampler is the original wave. The resonance ellect becomes more accentuated when the conditions next to the state of maximum amplifieation reacl their maximum extension before and after the resonanee point, and therefore when the transfer from the subcritical to the supereritical point is reached over a wirle bottom having as slight a slope as possible. Fig. 12 slows the results of calculations male witl a computer of the Universiby of Kyoto with the starting rata. [27]. The values of $P, u$ and $\eta$ at the time of $t=0$ are reconstructed in $(\mathrm{A})$, (B) and (C), respectively on time point zero (S.0). The thick lines in (B) and (C) show $u$ (velocity of current) and $\eta$ (elevation of surface) for appropriate time points. Tt is shown that the maximum of high-uater and the maximum current velocity ocar when the perturbation approaches the upper end of the sloped bottom.

The resulting from the action of the sloped bottom and of the resonance depth, is to be considered the only efl'eel as the meaning of the slope and of the resonance depth one is not soprarable.

It is to be underlined, however, that the more the slope of the bottom grades the more the amplitude of the clevation of the sea level increases. Thus, the phenomenon of resonance does not take place in one single point. It is ratler to be understood as a complex effect over a more or less large area. In part TI $\left(^{3 \cdot 1}\right)$ of their work the above named anthors show that the viscosily effeet is negligible was far as resonance phenomena are concerned, and that furthermore the high waler originaling from a clearly larger climensioned alepression viewed with respect to the linear scule of the sloped botiom, does not provoke sizeable clanges (v. p. es. fig. 5). At last they prove that lie effects of the meteorological agents can only be expressed in terms of a gradient of atmospheric pressure. Thus, the influence of the wind [estimated, for instance, for the Adriatic by F. Stravisi $\left.\left({ }^{35}\right)\right]$ may as well be inclurled in the same exleulation scheme. Tn other words, the same linul of approximate solution is valicl for a meteorological perturbation taken as a whole.

We will see that the consirlered effect concerns very closely the Gulf of Venice. 


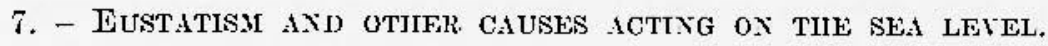

After the theoretical references of the previous numbers, we are now dealing again with the situation between earth and sea in the area of Venice. Tlis situation depends on the motions of one or the other or - as usually - of botll of them, so that the gratual increase or decrease of the level difterence between reference-points on land and the mean sea level $(l, m)$ is the result of the water and earth relative motions.

Generally spealing, the $l m m$ is presently increasing on our planet. The reason is seen in the progressive increase of air temperature in the last century (at least until 1940) and in the consequently more intense ice-melting. This inlerent increase, for which the term of "eustatism" is also used, has been estimated with a mean value of 1.1-1.2 mm/year for the last thirty years.

Sucl $_{1}$ estimates are extremely delicate. They are chiefly based on tide gauge data: the lide gauge sites are, of course, under the influcnce of local perturbations which may disguise - as they really do - the course of the phenomenon under a worldly aspect. This gives rise to inevitable perplexities and downright contralictions.

In this regard it may be nseful to call the attention on the results of a study by William L. Dom and David M. Slaw of the Lamont Geological Observatory ( $\left.{ }^{36}\right)$ after which the sen level of the last century is connected to the belavior of air temperature. On the basis of studies by Willett ( $\left.{ }^{37}\right)$ and carried on by Mitchell $\left({ }^{38}\right)$, a yearly whole temperature growth of $0.8{ }^{\circ} \mathrm{F}\left(0.4^{\circ} \mathrm{C}\right)$ was in course between 1880 and 1940 , with a workly temperature growth in Winter of $1.2 \mathrm{oF}$ (0.60 $)$ in the same period (fig. 13, upper part). The lower part of fig. 13 slows an even larger annual temperature increstse of $1.6^{\circ} \mathbf{F}$ $\left(0.9^{\circ} \mathrm{C}\right)$ and one of $2.4^{\circ} \mathrm{F}\left(1.3^{\circ} \mathrm{C}\right)$ for Winter periods for the latitudes between $40^{\circ}$ and $70^{\circ} \mathrm{N}$.

Since the beginning of 1940 a new fact is observod: an inversion of thermic development. The moderate cooling ofit which took place after that year compensater by about $30_{\%}^{\circ}$ the temperature increase of the period 1880-1940.

Another climatic parameter became subject to a similar eficet: the rain. A recrease of precipitations during the first 40 years of this century was ascertained, followed by an increase of raniness after 1940. This temperature behavior was reflecterl also on the sea levels. Tonn and Shaw elaborated the observations of nine tide gauges stations 
on the U.S. Atlantic seabord. They divided them into two series, one from the begirming of observations in 1939 and the other from 1940 to 1960 . They also calculated with the lesst squares methor the rectilinear behaviour of each series for exch station (fig. 14). All stations except Portland showed a trend to increase up to about 1940. After that year all the stations except Portland, Charleston and Galveston show a tendeney toward a clear decrease of the rise of the sca level, although the rise went on in all nine stations. Portland is undoubtedy abnormal, Charleston furnishes incomplete rata. before 1942 , while othler stations are under the action of natural and oceasionally artificial local factors. With the exception of Portland and Charleston, the mean rise of sea level with the other seven stations before 1940 amounted to $0.7 \mathrm{ft}(21 \mathrm{~cm})$ for a fity year period. Between 1940 and 1960 the increase of sea level averaged $0.4 \mathrm{ft}(12 \mathrm{~cm})$ for a fifty year perionl, which rejuresents a $40 \%$ rlecrease of the rising tenrlency. The thermic expansion of the surface layers of the Ocen (with a thickness of some $400 \mathrm{~m}$ ) may account for about one em only of the observed changes. The level incresse is attributed almost entirely to the ice-melting in the ligher latitudes, so that the temperature recrease beginning with 1940 resulter in a rexluction of ice-melting which seems to give a reasonable explanation to the lessened degree of growth of the sen level.

As suggesterl by the above autlors, it must be underlines, lowever, that the here reported values of the trend to rise are not typical of the world's sea level and therefore camnot be attributed entirely to iee melting. In lact, the elaboration of the tide gauge data from the U.S. Pacific consts slow a rise of sea level which is about half of that obserwed along the Allantic consts.

Therefore, a maximum of enution is required when forecasts on the belavior of eustatism are to be mude, especially witl regard to the present phenomenon of inversion of the wordly average temperature. The latter aspect appears to have been completely neglected in the elaborations of the experts engaged in finding solutions for the problem of Fenice.

But these are not yet all the causes apt to contribute to the variations of the sea level. It was observed that the sea level of each hemisphere is higl during its autunn and low during its spring $\left({ }^{30,40}\right)$; accortling to a first conclusion, the principal change of the mean level is to be strtributed to the variations of rlensity in the Ocen (v. 9.3). 
The atmosplieric pressure has a tangible effect, too, which is stronger in high latitudes than in the low ones. Tlus, in the Pacific as well as in the Fortl Atlantic the effect on the variations of the level, temperature, salinity of the water is much less important than that of atmospheric pressure ${ }^{(-1)}$. This is shown, for instance, by fig. 15 which gives a comparison between sea level and behavior of atmospheric pressure along the Southern coast of Iceland.

Quite a diflerent aspeet is taken by the same phenomena at lowcr altitules. A stuly on the variations of sea level at the Bermuda Islands sliowed (11) that the wave of maximum temperature in the Ocean progresses downward by some $40 \mathrm{~m}$ per month and reaches its deepest penetration at ubout $200 \mathrm{~m}$ in Janums and February. In the warmer months an upper thermoline of a mean deptil of about $80 \mathrm{~m}$ gradually flattens as the thermic wave moves downwart. $A$ detailed work of calculations on data of temperature, salinits, density and dynamic anomaly (understood as correction by ems of the conversion of depths measured in real (lepths) has shown that fundamental isostatic variations take place only in the upper $2,000 \mathrm{~ms}$.

A further complex incuiry $\left.{ }^{(41}\right)$ on the tirle gauge observations made at the Bermurlas from June 1954 to May 1962 led to the results summarized in fig. 16, which shows that for the IBermuda area the predominant effect is the so-called "steric cflect", that is the change of level brought about by the rleviations from the dlepths of normal pressures as a result of volume expansions.

Therefore, the results of research on the sen level near the Bermulas and near Iceland confirm previous conclusions gained from studies of the Pacific Ocean: the variations of sea level are attributable to a very large degree to the "steric eflects" in low latitudes (comneeted to dynamic anomalies associated to the thermic wave) and to barometric eflects in ligh latitudes. These conclusions are based on the contrust between the youry zonal thermic condition in the oceans and the yearly pressure variations in the atmosphere.

This is not yet all. Other complications arise from the fact that even the Oceans are animated by free oseillations. The Nortl Atlantic, for instance, slows considerable free oscillations of which recently the fentures of the first three grivitational modes witlı periorls of 21 , 14 and 11 lours respectively, and structures of one, two and three amphidromic systems have been studied.

It is true that the above described facts are attenuated in their 
effects if estimates cover more year's. The remaining values are not easy to estimate. Besides, although these phenomena were ascertained for the Oceans, this does not necessarily mean they do not apply, to a more or less limited extent, to the inland seas, especially if they show fentures like the oceans, such as the Meliterranenn (*).

It must be concluled, therefore, that the exact valuation, based on selection, of the sea level variations are any thing but easy. Presently, every foreeast is made more problematic by the inversion of the world's temperalure as mentioned subove.

Let us look again at the $A d r i a t i c$.

On the basis of data reported by Mosetti (4A) (Table I, page 216) I wished to determine the bchavior of the $7 m m$ in the course of the last ilecades for some ports of the Dalmatian and Istrian coast (**). Figures $1 \bar{i}, 18$ show in graphs the values of the $\mathrm{lmm}$ for Ragusa, Spalato and Buccari on the Dalmatian coast and for Pola and Rovigno on the Istrian coast. The straiglit dots-and-dashes lines were calculatel after the least squares methot. It is observed that the available data were too few and had too heavy deviations to allow secure approximations. The results are thus to be considered merely indicative.

For Ragusa a $7 \mathrm{~mm}$ mean annual increase of $0.74 \mathrm{mms}$ could be found. For Spalato the mean annual increase was of $2.2 \mathrm{mms}$ in the examined 14 year period the strong analogy of the $7 \mathrm{~mm}$ behavior of Ragusa and Spalato between 1958 and $196 \pi$ is striking). For Buccari (in the Gulf of Quarnaro) the increase from 1950 to $196 \pi$ was $1.35 \mathrm{mms} / \mathrm{year}$. For Rovigno d'Istria there were $2.3 \mathrm{mms}$ of annul increase from 1955 to $196 \pi$. At Poln the observation period of tide gauges was longest, lasting from 1897 to 1921 (and resumel in 1962). Until 1921 the mean annual increase observed was only $4 / 10 \mathrm{mms}$.

(*) S. Polli (*is), for instance, values simultaneous annual oseillations of the mean level of the Mediterranean sea of an amplitude of abont $11 \mathrm{cms}$, with maxima in November and minima in January.

$\left(^{* *}\right)$ S. Polli determined the value of the century-olel variation of sea levels for II Italian ports. The mean value of the variation for the Italian seas correspondis to an increase of the sea level of $16 \mathrm{cms} / \mathrm{century}$ against the 11 cms/century of all the seas of the world. 
Evitlently, the result of the calculations cannot afiord sure conclusions, as without any doubt there are influences of local phenomena whose effects ennot be ensily caught. On an average, however, it appears possible to state that the mean level suffered a major mean annual increase from 1954 to 1964 from Ragusa to Rovigno. To which extent are these results influencel by the "apparent" increase of the mean level to the strong dynamic variations of the sea level due by transient depressions caused, especially in the High Arlriatic?

\section{8. - StBSETDENCE OF GROUND, BRADYSEISM.}

8.1. After summarizing some of the reasons responsible for the increase of the sea level in the work, we oome to the phenomenon of grount subsidence which is intimately comnectel to the ajplarent increase of the sea level at Venice.

A general phenomenon of subsidence appears to be attachet to the Arriatic are, at least from the Tagliamento river mouth to Ravenna; this subsidence is certainly active in the area of the Po delta, where it has reached exceptional proportions. Concerning the thelta, the chief, if not unique, resson of the ground flexion was well detected at its time: the disorderly extraction of methane containing waters. I covered this argument exhaustingly in previous papers and would not repeat myself here $\left({ }^{16},{ }^{17}\right)$. We lave to limit ourselves to the problem of our interest: Venice.

A trustworthy comparison of levelling measurements carried out in a defined area would require levelling lines expressly set up there, in possibly remote times and remeasured at regular intervals witl the same metlods and the same exactness. Sucl conditions ditl actually not prevalil in the Venice area before $1970\left(^{(49}\right)$.

The Italian Military Geographical Institute (T.G.Mr.) earried out some precision levellings in the last 100 years, the first begun in the last tecades of the past century and finished in 1908, the secont in 1925, a high precision line Genoa-Venice in 1942, a new fundamental altimetric network in 1952 and a ligh precision levelling in 1968 , to which must be atdet the levellings carrier out by private firms in 1961 and 1964, for the account of the "Mingistrato alle Aeque".

Thus the picture is one of lieterogeneous surveys (as to precision and methods used) made in suntry times with a seanty number of 
common levelling-murks. Anyway, it is not my business to criticize the results.

I am limiting myself to report the comparison betwen the various levellings made at the levelling-mark of Punta della I)ogana (Santa Maria della Salute). This may be summarized in the following results: between the 1942 and the 19131 levellings the mean ammal subsiclenco (in a time interval of 19 years) was $3.3 \mathrm{mms}$; between 1961 and 1968 (i years interval) the mean ammal subsidence was 2.0 mms. The mean annul flexion between 1942 and 1968 were $2.9 \mathrm{mms}$. All measurements taken at levelling-mark Punta della Dogana are lying within an uncertainty band of over $\pm 1 \mathrm{~cm}$.

The ticle gange measurements showed a mean annual increase of the $7 \mathrm{~mm}$ in the orter of $1.2 \mathrm{mms}$, attribntable to eustatism.

Concerning the comparison between the tide gange data of Santa Maria della Salute and Trieste a difference of level was observed, witil a clear and progressive increase for Venice, beginning around 1926.

The subsirlence slows no signs of continuity or linearity: there was evidence of overlappings of obvious ondulations. It must be emphasized, however, that the Lagoon tide gauges lave no sufficiently long observation series to enable them to seduct the possible perioticity of the overlapped waves and tilieir funclamental characteristics (49). Thus, the comparison with the altimotrical results is only one of first and rongh anjuroximation.

Angway, on the base of altimetric and tide gauge observations, it apperars possible to conchule that the subsidence in the last 40 years (1929-1967) for the area of the Centre of Venice-Marghera is in the order of 2.7-3 mms per annum. The subsidence movement apperis to lave set in between 1925 and 1930 and is still in course.

Owing to the above mentioned reasons, these results should be accepted with mental reserve.

These reserves concern, of course, all conchsions and illaticns drawn by starting from the above data, and among them the consideration of a total subsidence of the Venetian ground of some $20 \mathrm{cms}$ since 1900. By accepting this date one was induced to believe that the effective high water, attributable to mere astronomical and metcorologieal reasons, would not become subject to appreciable increases in the last decardes, which would lear to the conclusion that the increased frequency of the high water should be attributable to the progressive increase of the relative sea level, as the sum of the progressive inherent increase of the sea livel and of the contemporaneous subsi- 
dence of the ground of Venice $\left.{ }^{50}\right)$. Such a conchnsion is doubtful, of conse: a sum of meertainties cannot bring forth a sure date (*). It is my conviction, supported by what I have to say further on, that the causes of the more frequent rises of higl water cannot be limited to the two just discussed.

8.2. The results summarized in the previous paragraph, about: which their very authors did not spare reserves, have met with ample opposition. According to some it is not trustworthy, due to the lact that three recent: levelings attribute to the main point of the snmmit of the water gange in the Calle Loredan (townhall of Venice) a subsidenee represented by three different values:

$\begin{array}{lr}\text { Magistrato alle Aeque } & 9.94 \mathrm{cms} \\ \text { Public Works Ministry } & 18.60 \mathrm{cms} \\ \text { Military Geographic Institnte (IGM) } & 25.00 \mathrm{cms} .\end{array}$

"The said discrepancies of over double and triple the first bradoseismic quantity are incompatible and thus indicate crrors in the various levelings" (52). The anthor of this statement indulges in a delailed criticism of the matn points chosen for the varions levelings and of their more or less marked unsuitability as well as of the strident contradictions of their results (**).

To my belief, the most interesting part of 0 . Spagunolo's work ( $\left.{ }^{52}\right)$

(*) G. Supino (51) makes some remarks on the nethod followed by Mosetti about the estimates of high water: among other things, he reproaches hin to have taken into consideration the mean anumal level of the year examined rather than - as would have been more correct - the "theoretical" sen level as resulting from the subsidence of the grount and from the rise of the sea. But eren if Mosetti's determinatinns should he Falid, accorting to supino one rannot infer that the frequeney of the of fective high water did uot grow during the past decales; such rise appears proves if one looks at the fact "that from 1914 to 1943 (that is in thirty years) there have been four high waters, whereas from 1944 to 1969 (that is in 20 years) there have been eleven".

(**) Certainly, I canuot interfere with these critieisns. I am only observing that as far as the brilge over the Crevala River is concerned (in the neighbourhood of Conegliano), the abutment on which the main point is molunted appeared restored at the end of November 1972 . Besides, I note that thes tatum point of the I.G.M. leveling is at about $500 \mathrm{~ms}$ distanee from the Crevada, at $0.50 \mathrm{~ms}$ from the Xortheast eoruer of the buil. cling "Ristorante Nazioni Unite". I also underline the fact that this main point is on the inmediate nargin of National Jighwas $\mathrm{Nr}$. 13 and therefore subjected to very heary traflie movements, largely by heavy vehicles. 
is where he refers the subsidence to elements of construction certainly rommectel with the mean level of sea water "such as the bridges linking the numerous islands of Venice to each other, the drinking water wells, the fortifications (...) and any other work, having a project date, or a date of actual buililing operations, which bears connection to the sea level and which should be retracable with the State Arehive or in the Venetian libraries" (l.e., page 34). The research done by the author let him to retrace thrwings and building projects in arehives ant libraries which show, for instance, that the P'onte della P'aglia bridge, built in 1360 , was at the summit of the arel at a distance of "pie $81 / 2$ " (1.e., page 35), that is about $2,96 \mathrm{~ms}$ from the "Comm dell'acqua" (mean sea level of that period). This value diliers only little from the present one (*).

Very small differences are resulting for the Rialto brilge, the Ponte telle Guglie bridge and for otler bridges, and the same comclusion is ralid for the other century-old works such as the Forte di Sant'Andrea, the navigation basins (**k), the Filla della Malcontenta, the rain water collecting basins as those of Campo San Trovaso, of Pellestrina etc. (***).

Notwithstanding, I think that a clearance of $10-15 \mathrm{cms}$ may well be presumed between the old and the present sea level, althongh a part of the sinking of the construction items must certainly be attributed to the inevilable subsidenee of buililings of several centuries of age such as brilges, forts, columns and other works bound to sink more or less into the supporting ground.

(*) Spagnuolo translates 8,5 Venetian feet into $2.80 \mathrm{~ms}$, which suggests that he consistered the Venctian foot inferior to the size of 0.348 ins which is commonly used.

(**) Concerning the old navigation basins hetween lagonn basins and ship canals on land, Spatgutuolo points out that they functioncel regularly. "After four humbed years of existenee those impressing hydraulic works are still in perfect working contitions" (l.c., mage 49).

(***) A particular upon which the author of the above work ealls the reader's attention regards the two large columus rising on the Piazzetta di San Mace, at the basin's margin. These columus were erected in 1172 and "always remained at the same level of their erection as can be proved by examining the old prints showing the Basin of St. Mate" (1.e., page 57). If $I$ : $m$ right, some experts tried to explain the unchanged altimetrie value maintained by the columns for eight centuries from the? "backiflow of the groumd under the bulk of the buililings of the Library of the looge Palace" (l.e., pare 55 ). I lope this is ouly a controver'sial silly. 
Without denying the subsidence in course, other scholars contest its officially admited value, party on the groumds that some local subsilences caused by ligging deep canals (such as the collapse of part of the Fort of Sant"Autrea) or by erosion or other casual causes "are often presented as saggings of the whole lagoon basin" (Pisenti aut Rosa Salva (53), page 10). Without excluling subsidence plenomena, the mentionel authors affirm that they are present to a much lesser extent; if the suggested values were true, many several centuries old brilges womlil be nnserviceable sine long.

lu any event, even if the subsidence of the lagoon gromud chunot be denied (with its actual amount probably inferior to the one suggested by some experts), one fact should be, according to me, strongly underlined: the said subsilence tends to increase toward Chioggia, reaching exceptional values at Porto Corsini. In 1967, in the preface to my work on the phenomena of abnormal subsidence arount the Po Delta I wrote: "It should not be forgotten that within the area. subject to a subsidence reaching at some spots $3 \frac{1}{12} \mathrm{~ms}$ in less than a dectie, there are towns like Fenice and Ravenna, where in the course of recent years the underground is suffering flexions which may be defined abnormal" ("6) l.c., page 332). And since the subsilence of the Delta. Region was attributed as early as 1958 to the disorderly extraction of methane containing waters out of nnderground layers, I added (l.c., page 398): "The eflect of the extraction which is more than obvious in the area where the drills were brouglit down may easily extent to a certain alistance from the extraction sites. In this regard it slowid not be forgotten that the flexions brought about in Long Beach after oil hal besen extracted reached ont considerably to some bordering areas and mate themselves felt also in the-Los Angeles area, at about $40 \mathrm{kms}$ disturee $(\ldots)$. At about $16 \mathrm{~km}$ distance from the area of maximum flexion (Ca. Ventrumin), the subsidence observed between 1951 and 1963 was about $35 \mathrm{cms}$, laving reached the value of as much as 20 cms from 1958 to 1963 in only five years, three of which afer the 'milkings' lad been stopped. It should be borne in mind that $15 \mathrm{kms}$ Forth lies Chioggia, and Venice at about. 35 kms from Porto Caleri..." I concluled that, should those correlations be comsidered daring, I would be glat if my error could be provel. I repented the same conceptions in $1970\left(^{47}\right)$.

Regurling the growing subsilence from Venice to Clioggia and to Porto Caleri, a few years aften laving published the above considerations an expert wrote [(44), page 253]: "The fact that Clioggia sub- 
sided more than Marghera and Vonice and that Porto Corsini presents still stronger motions, would suggest that at least one of the hypocentres of the subsillence is situated in the area of the Po Delta. Besirles, the subsidence of the Delta has already been proved by precision levellings, apart from tide gauge data".

This confirms my repeated previous tedarations, which hat fallen on general indiflerence or ilenial $\left({ }^{47}\right)$.

To conclute these short notes, it may be observed that the opinions concerning the stability of the underground of Venice and its lagoon are most divergent, langing from those whicl deny flatly any, oven the slightest bending to those which consiler subsidences of such proportions as to suggest the submergence of Fenice under the sea level within a few years (*).

9. - GrOWING FREQUENCY OF "IHGH WATERS" AXD ITS INTERPRETATION.

9.1. There is no tloubt that the subsidence is happening; maybe it is exaggerated in one direction and in the other, so far as the extent is concernet.

$\Delta$ s a matter of fact, unfortunately, the "high water" days in Venice are alamingly increasing. Spenking only of the last decades, the tirles of over $110 \mathrm{cms}$ pass from the 2 high waters of the 1916 1926 period to 8 between 1927 and 1936 , to 3 from 1937 to 1946 , to 10 in the decade $1947-1956$ and to 29 in the decade $1957-1966$, with a trend to further increase in the following years. If one takes into account the levels over $70 \mathrm{cms}$, one passes from the 164 cases betwen 1964 and 1966 to 197 from 1966 to 1968 and reaches the maximum frequency of the unprecedent 295 cases between 1968 and 1970 (Pisenti, Rosa Salva, l.c., pages 9 andil 10).

I am now ealling your attention on a dotail to which I attribute much importance. Generally, the graphs of sea levels are redistributed on continuous curves. I think that in this order of examinations such a procedure tend to disguise the abrupt variations in the behavior of the inquired phenomenon. In their above said work the $\Delta$ mericans

(*) P. ex, according to some the sinking (for geologrical reasons) was about $1 \mathrm{~mm} /$ year in the last 1800000 years, followed by $5-7 \mathrm{~mm} /$ year of the last lustrums after the water-fold reduction; if one adds the rise of the sea level by eustatism, Venice should now be floating with in anybody knowing it. 
Domn and Slaw $\left({ }^{36}\right)$ prefer to averuge along straight lines with the least squares method. Such a procedure. if applied for instance to the dingram of mean levels recorded at Punta dolla Salute (fig. 19) witl respect to $1935-1950$ and $195.1-1969$ respectively would revenl a solution of continuity in the tendeney of the plienomenon of higl waters around the year 1950 .

Moreover, this solution of rontinuity in the behavior of the $l \mathrm{~m} \mathrm{~m}$ around the year 1950 may also be observed in other ports of the West coast of the Gulf of Venice. We consider, for instance, the behavior of the annual $\mathrm{lmm}$ of Porto Corsini South of the Delta, as resulting from the observation data for the 1934-196i periou [ $\left[{ }^{(4)}\right)$, pige 246], reported in fig. 20, One notes clenrly the alvupt leap of the tendency to rise, arount the year 1950.

But a discontinuity around that period becomes evitlent also from other studies. In particular, Ing. Paolo Pirazoli (5i) based his research on the yearly $l m m$ elaborated by the Ilytrograplice Office of the "MIagistrato alle Acque" of Venice on the basis of the tide gauge recordings of the yeriod 1871-1968, that is from $18 i 1$ to 1906 of the that recorded by the tidle gauge of Campo Santo Stefano, and from 1900 onward of the data of station of Punta della Salute. The thata appear rather scibtered, but on the whole they show a tendency to increase (fig. 21). In order to eliminate overlappings at tributable to jartionuar meteorologieal conditions, errors or otler casual reasons, Pirazzoli chose a certain filtering opcration by replacing every annul value of $\mathrm{lmm}$ by "thle arerage of a certain number of consecutive values of which the given value is the centril eloment". Tlie results are summarized in the first two figures of the mentioned work. The anthor notes that "on the whole it may be observed that the curves of mean currents present the following common fentures: a period with small oscillations around a rather constant value (until about 1890), a jerioul of growth almost linear between 1890 and 1910 approximately; a period witl important oscillations around a tendentially growing value between 1910 ant about 1950, another almost linear growth perioul beginning from 1950 forward" (l.e., page 3). The obtained curves were then replaced by a line mate up by sections of straight or parabolic lines, after which the parameters of the various sections were eniculated with the least squares method after the points of discontinuity had been closen.

It will be noted that in all eases the year 1950 constitutes a point of discontinuity. The siperimposed oscillation, too (fig. 21), shows 
a strong regain of the sea level toward 1926 , attributed by Pirazzoli to the industrial comeback of Porto Atarghera, but the true thscontinuity clearly marked is that around 1950 .

We remember that, beginning with that late, there were the abnormal ground subsitlence phenomena brought about in the Po Delta region by the disorterly extraction of methane containing waters and that in Fovember 1951 there was one of the strongest floods of the Po in the last centuries.

We have to stop for a certain while on these events as they are intimately connected with the alarming frequency of ligh waters in the Venetian lasgoons (*).

\subsection{Epeirogenesis and sand-filling in the High Adratic. The ITest coast subsidenec and its consequences.}

As was recallet above, after a long floot perioul, the Po River broke its banks in autumn 1951 in the neighbourhood of Occhiobello and floodet into a large area of the Delta. It reachet the sea over a large front. In the long perioul of high waters and flools, which was the common fenture of all rivers flowing into the Adriatic, an very large amomit of turbit and crouled material was dragged into the sea, the equivalent of whish is normally conveyed only in tens of years.

This has certainly contributed to accentuate the difierence between the menu depths of the Jow and the High Arriatic and to increase abruptly the natural tentency toward a conversion of the periods

(*) Periodical analyses of the series of sea levels of some Italian yorts have been attempted. S. Polli applied the cymanalysis to a fifty year series of 'l'rieste (1890-1942) ant to a seventy year series of Venice (1872-1941) $\left({ }^{55}\right)$; he obtatinel components of $22 ; 11.3 ; 8 ; 5.5 ; 4 ; 3 ; 2$ years. The wave of 22 years, which is common to almost all elimatic analyses previously made by others, corresponds to twice the cyclus of sunspots and is considered by many authors as a fundamental cycle. It would be followed by harmonic cycles of $11 ; 7.5 ; 5.6$ years.

$A$ spectral analysis of the data pertaining to the $l m m$ of Porto Corsini, Venice, Genon and Trieste was suecessively carricd ont, after the Fourier melhod, by Caputo ant others $\left({ }^{5 B}\right)$. The annual periods found for all title gauges were $20.0 ; 12.5 ; 8.3 ; 6.7 ; 4.0 ; 3.4$. 
of the forced and of the free waves to common valnes, which restuteal in an increase of amplitudes of the "high waters", provided the meteorological perturbations remain nnchanged.

But, going further back in time, we find another clem coincidence between large floods and following "ligl water" increase. 1926, 192 and 1928 (as woll as 1951) were years of large floods of several Forth Italian rivers [((57) Table I]; particularly, the major floouls of the Po in the present century were, besides the above said of 1951, those of $\mathrm{Mlay}$ and $N^{\top}$ ovember 1926 [( $\left.{ }^{57}\right)$, page 163]. Beginning with 1927 the frequency of high waters increased rapidly and caused the simultaneous apparent increase of the mean level. In Venice $\left[\left({ }^{5}\right)\right.$, page 7$]$ the tides of equal or higler level than $1.10 \mathrm{~ms}$ over the $\mathrm{lmm}$, which between 1884 and 1926 lat been only three, rose abruptly to 10 in the 12 following years between 1926 and 1938 . T'o impute lockl clunges to industrial settlements in the Marghera area would bet rather of the point, firstly because the beginning of those settlements was morlest as it contintred to be for many yoars (**), and because high waters accentuated at the same time also elsewliere, between Venice and Porto Corsini. It is my conviction that the principal cause is to be sought in the sudden mbalance between enstatism and tectonic bending (the latter to a much slighter extent) on one side and the action of slow sant filling due to abnormal aftuxes of turbid and croted materials on the other, with a clear arvantage of the latter, and in the simultaneous growtl of the interaction between atmosplere and hydrosphere (partly due to the lightening of the water as its salinity decreases), the meteorological perturbutions being equal. The disappearance of high waters in the 1938-1947 decale (and the simultaneous apparent standing of the $7 \mathrm{~m} \mathrm{~m}$ ) indieates that the above mentioned unbalanee was decreasing with the return of normal turbid matter components, witl the return of salinity and the persistent eustatism.

Int the natural equilibrium was again broken in 1951 with the tre-

(*) "Matryera was created and huilt on a limited scale. Iater, in contrast with Folpi's sersibleness, the area was opened to new initiatives [(5"), p. 98]". The expansion work began in 1919 and emsled in I935. It is to he noted that in 1922 there were 16 mills, while in 1955 , when Gizseppe Volpi long since had heon deat, the number had reached ] 80 ! 
mendous November flood and the following surkten increase of sand filling in the ligh Adriatic.

And here I deem it suitable to revert on the strugghe between earth and water in the Po Valley, a suljest alrearly covered in Sr. 2..

It is known that between one glacial period and another the Po depression passed repeatedly from the continental to the sea-condition.

However, it is to be observed - as wites $P$. Leonardi - "that with each return into the Po depression the sea shalloned more and more and reduced its extent, for despite of the progressive subsidence due to the serlimentary material compaction and to the still acting positive bradiseism in the coastal areas, the wandering swelles river of the Po Valley depositer, in the omersion periods, such an amomt of alluvium that the Fo Gulf was gradually filled up" $\left({ }^{60}\right)$.

This filling process of the High Adriatic gradually acentuated during the latest centuries in the course of regulation and damming of the rivers. Thus, the Po Delta arvancel by some $25 \mathrm{~ms}$ a year (ii) between the XIIIth and XVIIth eenturies. Between 1600 and 1804 the growth was about $73 \mathrm{~ms}$ jer year. "The difierence is explained by artificial flamming through which the major part of the suspended material which was first abundantly lost along the river beds was now carried along and kept in the curront." $\left({ }^{62}\right)$. Witl further reference to the Po, Mirinelli (os) calculated that the mean growth of the Delta in the seventy year perior $1823-1893$ was in the orcler of 0.762 square $\mathrm{kms}$ per year.

An estimate of suspended solid material, carried by the Po toward the sea and in various ways distributed on the sea bottom by the enrents, was made as well. The amount varies, of course, with the climate and the seasons. Thus, in the period of ten years - from 1914 to 192:2 not very rainy - the quantity of material suspended in the Po and auried ofi by it resulted to be about $17 \%$ million cubic metres per year ( $\left.{ }^{64}\right)$, whereas in the above said seventy year periorl Iarinelli estimates that the mean annual aleposit was in the order of 29 million cubie metres. T'o the suspended material carried ofl must be alded, however, the dragged part, that is another $10 \%$ of solirl suspented material.

Anyliow, assuming that every year the Po conveys about 30 million enbic metres of fine solid material toward the sea, a brief ealeulation shows that this is sufficient to cover an area of around 3,000 
square kms (measuring about $50 \times 60 \mathrm{kms}$ ) with a $1 \mathrm{~cm}$ thick layer. The distribution would of course not be uniform, especially due to the currents.

But the Po is not the ouly river which flows into the High Ariatic, although the largest. Particularly the Venetian river's from the Arlige: to the Isonzo carry their aggregate contribution of tubiai material into the Gulf of Venice. According to the datin published by the Iy rhograplic Office of the Magistrato alle Acque, the Mlige, for instance, carried in 1933 suspended solis material, as ascertained from accurate turbit material measurements at Bowra I'ismi, in the amount of 1,096500 tons $\left({ }^{65}\right)$. In otlier worth, in one yoar the Atlige carries, as a gross estimate, an amount of dissolvet material into the sea which covers an area of abont 100 square $\mathrm{kms}$ with a $1 \mathrm{~cm}$ layer.

This is not all. Iruring the flood periods the afflux of material is enormously higher. For instance, when it is swollen, the Iooira River carries a water amount of 312 times as much as normal. This relation decreases sizenbly if a river flows throngh forest areas: the ratio is only $70: 1$ in the case of the Rhine River downstron the Latko of Constance (T) Marchi, l.c., ]. 247). At any rate it is always on the very high side. During a flood perion a river is able to convey an amonet of nubomml material into the soat, which nuder normal conditions he conveys in tens of years.

In this way, the lilting my of the bottom of the High Arbiatic by nuloading of fine solit materials through the rivers flowing into it exceeds strougly the level variations cansed by enstasism. Remaining the perturbing canses unvarient, the amplitude of the oscillations in the Higle Melriatic slowly tends to increase. This increase turus abruptly stronger with sudten flood waves (1879-1582, 1926-1928, sinee 1951). Bint tle raise of the sea bottom lorings about a still more insitions variation: the increase of the proper period of the stretch of sea subject to free ostillations, especially those of the High Ariativ. As it is known, remaining the other anditions muchanget, this period is ajproximately inversely proportional to the square of depth and grows as the latter diminishes. Since, for instance, the free wave of 11.8 hours is next to the lablf-day lide, even a very light increase of its period - boing in the resonance zone — is apt to canse langible increases of amplitude.

Buginning with 1951, however, two other reason lave contributed to accentrate the high waters in the Vometian lagoons: 
1) The more frequent repetition of the floorl-waves in the Venetian rivers (*): Tagliamento and Livenza (February and November 1951, Oet. 1953, Dec. 1954, Nov. 1959, Nov. 1961 and the most violent of Nov. 1965 and Nov. 1966), Piave and Brenta (Nov. 1951, Oct. 1953, Oct. 1960, Nov. 1965 and the strong one of Nov. 1966), Arige and Bacchiglione (Nov. 195̃1, Oct. 1953, Aug. 1966 and the ratier heavy one of Sept. 1960, Sept. 1965 and Nor. 1966). The data are taken from Piccoli's mentioned work, Table $I$. The progressive accentuation and frequency of flood phenomena with the consequent progressive increase of conveyance of material into the sea, as gathered from the IIylrographic Service of the Nagistrato alle Acque, is attributerl to the "recurrence of intense rainfalls in periods always closer to each other" (Piccoli, l.c., ]). 15̃).

2) The beginning and the progressive accentuation until 1964 and later of the bending of the Delta area and, bence, of the opposite stretch to sea bottom, especially in the section Porto Corsini-Clioggia. For the reasons given under 6 . this fact has created always better conditions of the amplification of free or forced waves propagating toward the coast.

9.3. Consequences of sudden variations of salinity in the High Adriatic.

Jet us now consider another aspect of the physical conditions of the Northem Aririatic Sea which is linked to abnormal afflux of (soft) water: salinity. It is lnown that the saltness in the inner seas is the lower the smaller is their communication with the Ocean, the lower is their evaporation and the ligher is the amount of river water. While for instance the salinity of the Rod Sea is in the order

$\left(^{*}\right)$ Conecrning the filling action of the Gulf of Venice by the Venetian rivers in flood condlitions (and thus eoncerning the higher hydrodynamic preeondition of "hight waterg") I would recall that on the basis of thata supplied loy L. Dorigo $\left[\left({ }^{58}\right)\right.$, page 7$]$ a first group of "lighl water's" from 1879 to 1883 must be adked to the periods from 1951 until today and from 1926 to 1938 , so that in 1879 there was one of the strongest floots of the $P^{2}$ of the last ecntury (Giamdotti, 1.e., p, 7). The antumn of 1882 was long remenbered for the tremendous floods of all Venctian rivers, beginning with the Arlige (Piceoli, 1,e., pages $156 \cdot 157$ ). 
of $45 \%$, that of the Baltic Sen is around $15^{\circ} / 00$, but it is well apt to fall under $10^{\circ} /{ }^{\circ}$ in the Gulfs of Bothnia and of Finland.

The flood periods bring therefore further influences on the properties of the Higl Arlriatio Sea. Tle enormous quantity of the water unloaled by the swollen rivers into the Gulf of Venice in the rainy periorls apply decp changes to the salinity of the sea water. The reduced salinity carries with it, among other things, a realuetion of density, of molecular viscosity and of surface tension (66). In other terms it makes the water lighter and more fluid. The extensiveness of this phenomenon concerns in the long run the whole Migh Alriatic, where the salinity is always considerably reduced after large floots ( $\left.{ }^{67}\right)$. If the atmosphere influences remain nuvaried (pressure variation in mms of mercury), the relation mereury/water is no longer 13.2, as with normal salinity, but tends to 13.5. The static level variation tends to increase, and be it only to a very light extent, but the increase becomes more appreciable on the dynamic field, when the trend is toward resonance conditions. In these cases (in whicl the static effect may be multiplied by ten to a hundred times) the decreasing molecular viscosity, density and surface tension may facilitate level increases in the order of sevcral centimetres.

Furthermorc, isostasy presupposes that per area unit on a conventionat surface (compensation surface) acts a vertical column of equal mass in any point of the considered surface. Therefore, that column has a different height according to its density: it is ligher if the matter is less dense and lighter. Pattullo $\left({ }^{a},{ }^{40}\right)$ proves that the major part of deviation from the mean sea level is a function of isostatic effects resulting among the sen pressure and density clanges (or volumetric changes). These eflects maintain a constant pressurc on the compensation surface (whicl may be the bottom surface). In collaboration with $\mathrm{F}$. Tisitzin, Pattullo proves that accoring to the results of tide gauge graphs recoried in the "International Geophysical Yea" the seasonal variation of the sen level is chiefly isostatic $\left(^{58}\right)$, at lenst in the larger portion of the Pacific.

As recaller before, an accurate research work on the variations of the sen level in the Atlantic areas of Iceland and the Bermurlas was conducted by Shaw and Donn (n. 7) based upon data of 19581962. Among the other results, a particular interest regarded the isostatic eflect deriving from the "steric effect" (linked to the variations of the water specific volume) and from the barometric efiect: 
the "sterie eflect" is by far predominant (in its posilive values) in the month around October (September-Terember), especially in the years $1955-1957$ and $196 \mathrm{~L}$ (in September 1955 with more than $24 \mathrm{cms}$ ), as appears by the way also from the montlyly averages of the entire period slown in lig. Iti.

What happens in the High driatic during and afier the great floods? The "steric eftect", associated Imaticularly to the strong lessening of salinity values, must reach considenable proportions anil lead to a level lifting of several cms. A transition and comprensation area on a subvertical layer is probably building 10 in these anomalous intervals foward tle Midlle Adratic, between Pesaro and Ancona, where even in normal times salinits (for instance in the coastal water opposite to Fano) is lower lowari SW and increases towar SE, as a consequence of the aflux of the waters from the Venetian rivers and particularly from the Po $\left.{ }^{69}\right)$.

In the flooil periods of the rivers flowing into the High Nilriatic and in the closely following ones the "lightening" of wators due to roducerl salinity may bring about rises of the sea level under the isostatic eflect, and salso prepare ilynamic phenomena of amplification of water motions, remaining the other conditions unchangesl. This explains why the years of major floods are also eltumeterized by a higher frequency of lighl waters ("i) markeil in the last tens of years as a consequence of heavier rainfalls.

What is expressed in this paragraplt may aprear partly cont rasting witl par. 9.2, but it must not be forgotten that these waters are "lightenex" and particularly suibuble to sufler and to enhance tle dynamic barometric effects; their mass is in any way that of the liquit layer of normal seasons.

\section{Conchisions.}

a) From what is observed muler $\mathbf{n}$. 5, and since the mean thickness of the sea in correspondence to the ileep basin of the Southern

$\left(^{*}\right)$ The oppesite effect, takes place, of comrse, when salinity grows after rainfalls are searee and rivers carry little water. The slensity increase may be suele as to canse "an effective contration of the sea folume which may be controlles also through the permanently lowered sea levels with respect to the normal level" [Alosetti (" $\left.{ }^{A 7}\right)$, page 4]. 
Alriatic may be consiclered constant, in view of the clearly larger extension of that basin and tle minor afflux of turbid material from the small rivers flowing into it, in view of the gradually thiming out mean thickness of the High Adriatic, it follows that (the other condifions remaining melanged) the amplitude of the slow movements of the sea - witl forced or free waves - in the neighbourlood of the Venetian coasts is subject to a slow but continuous relative growtl.

b) But the deptla clecrease of a basin (or of part of it) brings forth another consequence: the progressive increase the other conditions remaining unchanged) of the period of the basin's frec oseillations.

As I saik, the theory values the period as inversely proportional to the square root of deptl. Therefore, a decrease of the mean depth of the Figh Alriatic provokes an increase of the preriod of natural oscillations of the saik sea $\left(^{*}\right)$ which is all the more aproreciable if the natural oscillation of 23 hours can be attributed - according to Odklone $\left({ }^{21}\right)$ - to the free movement of the High Adriatic considered as a. gulf open to the large basin in the Sonth.

In any case, the increase of the perioxl of the free oscillations gives way to a very slow, but unavoiclable aproroach of [10] to resonance conditions, especially as far as referred to the diumal and semidiurnal ticles (**).

$\left({ }^{*}\right)$ If the period of the unimotal free oscillations of the stretch of sea between the Venetian coasts and the line between the Tremiti Islands and the lsland of Pelatgosa is 11.8 hours for a mean depth of $60 \mathrm{~ms}$, the period of the unimodal beromes 12.00 hours if the moan depth is retued by 2 ms.

(**) Coneerning the propagation of waves through the High Miriatie, the effect of frietion on the sea bottom should also be consideret. However, with the exception of natrow eanals and of very long perisils, it is extremely low.

Referring to equations [9] $\mathrm{or}[10]$, if we consisler the $\lambda_{f}$ corres]onding to natural oseillations, in the case of friction they will be no more jurely imaginary, lnut take a real part, always negative as the energy decreases. The roots in /. will be still imaginary, conjugater in twos, but no longer in twos equal and of opposite sign.

Let us lonk at the consequences. With foreed oscillations we have or $--\varepsilon_{r} e^{\prime / t}$ which is a partieular solution, while the general solution of the uulomogeneous cquations is $q_{r}-\varepsilon_{r} e^{\lambda t}-\sum \lambda, a_{r j} e^{\lambda t h}$.

The $A_{j}$ 's dejent on the initial conditions. Applied to the tides, these 
Horeover, it was observed on other ocessions that in basins subjeet to foreed oscillations there is a tendency toward the unification of the periods of such waves or of some of them with the periods of the free oseillations which the basin is capable to produce: uninodals, binotals..., or of some of them. In 1910 Oddone (ro) proved by experiments that a basin is able to change its configuration until the creation of a proper perioul in the order of the one pertaining to the perturbing force.

Is far as the Aubiatic is concerned, it is eertainly not fortuitous that the uninotal of about 23 hours is close to the dlaily tisle and that the free wave of 11,8 hours (approximately) is in the order of the half-riaily tirle.

In its natural course, this process is undoubtedly very slow. It is true that the basin's period may be lengthened by the slow raising of the bottom tlrough deposits of turbid material, but such lengthening may at the same time be contrasted by the alvance of the shore line.

This equilibrium is in any case unstable, sometimes failing; they can be exsily upset by slight elanges of the participating forces. For instance, elanges in the conditions of some rivers, caused by arti-

terms disappear rapidly: as $\lambda$, has a negative real part, e $\lambda_{j} t$ decreases constantly until zero: dinring the rlevelojment of the ticles, the movement dine to free oseillations inust be eonsidered finite: there remains only tlic forced oseillation properly speaking.

Secondly, frietion produces a light decrease of auplitude and a little phase displacement (11). We see, hesisles, a less perfect resonince. We have in fatet

$$
\varepsilon_{r}=\Sigma \frac{D_{j}}{\lambda-\lambda_{j}}
$$

and the resomanes is realized for $\lambda=\lambda$, which provokes the tentency towart the infinite of one of the terms which prevails therefore lecidedly on all the others. Due to frietion the resonane is no more as perfect. In fact, while $\lambda$ is purely imarinars since the perturbing forces are essentially periolical, $\lambda_{j}$ yet has one negative real piat. Therefore, $\lambda-\lambda_{i}$ is neper an. nulled.

Practioally, however, the difierence is not large, since the real part of $\lambda_{j}$ is always extremely small as an absolute value, from which follows that $j-i, j$ ean become very small, so that an almost perfect resonanee is enabled. 
ficial barrages, prevent an efficient counteraction by way of advancement of the beach without changing the slow reduction of the basin's mean depth by sand depositing, as in the specific case of the High Adriatic (*).

c) As was pointed ont repentediy, a vast part of the Polesine region, anyway slowly sinking lown in itself, suftered considerable subsidences of over $3.5 \mathrm{~ms}$ in some places as a consequence of the disorderly extraction of methane-waters in the Delta aren, begun in 1948 and continued up to 1960 and still in course in places hardly outsiule the Delta.

These sinkings have necessarily spread also to the coast area and to the sea bottom close to it (**). An analogons process due to concurring causes and in part to the same cause, took place on the High Adriatic coast from Venice to Ravenna (***).

Beginning with 1951, a progressive light decrease of the angle between the sea bottom and the water surface near the shore is thus going on along the West coast of the Gulf of Venice. Within the dynamies of slow sea-motions (linked to the transit of pressure va-

(*) The amplitude of oscillations in the High Adriatic may become subject - the other conditions remaining nnchanged - to an inerease also for other rensons: the progressive restrietion of the basin $\left({ }^{26}\right)$. This is what actually (thongh very slowly) hilpuens, in spite of the acting bradiseisun, with the advancenent of the delta on a front of several tens of kms which is piling up on the sea (at the rate of some 70 ms per year in the phase of lobated delta) $\left({ }^{71}\right)$.

(**) This is proved by the isokineties (from -20 to -70 cms/year) opened on the sea, but not only dnring the strentous milkings, bnt also after their interruption in the delta area (isokineties from -10 to -50 emsigear), with some still in conrse in 1967 [figs. 2-5 of $\left({ }^{2}\right)$ ].

(***) Beginning in 1950, at Jorto Corsini the annual frequeney of high waters inereases, certainly also on account of gronml subsilence. This is proved by the observation that the high waters of over or expal to $1,00 \mathrm{~m}$ follow a curve of always higher frequencies, lower than that of Venice in the beginning, but tmrning steeper and steeper beginning with 1962 and snrpassing widely the annual number of high waters observed in Venice. Thus, while from 1950 to 1961 (in a twelve year span) the number of high waters in Venice was 52 and at Porto Corsini 26 , it rose from 1962 to 1969 - in eight years - to 66 in Fenies and to as many as It4 in Torto Corsini [page 54 of $\left.\left({ }^{73}\right)\right]$. In a few years' time, hence, the frequency relation of the two places was inverted. 
rations) this is translated into a relative increase of the motion's amplitude, pursuant to the theory put forth under N. 6, which says that resonance plenomena may take place in the propagation of a way motion toward the coast when the sea bottom falls slowly lown with respect to it $(*)$, and that such plienomena are the more large the more the sea bottom tencls to flatten out parallel to the water surface.

The case observed by the Japanese $\left(^{32}\right)$ is summarized in fig. 12. From many points of view it seems to fit for the High Arratic: in fact, the depths occurring are of the same amonut. Also in the High Arlriatic the transit velocities of weather perturlontions, corresponding to resonance phenomena, are of the order of $\sqrt{g h_{0}}$ (for $h_{o}$ varying between 20 and $25 \mathrm{~ms})\left({ }^{2}\right)$. In two respects, lowever, the situation of the High Adriatic is definitely worse: 1) the case examined by the Japanese involves a (projected) distance of only 20 lums for the extreme depths of $10 \mathrm{~ms}$ and $8 \mathrm{~ms}$, while in the IIigh Adriatic the distance varies between 40 and $00 \mathrm{kms}\left({ }^{75}\right)\left({ }^{* *}\right)$, and presents thus a mean slope bottom clearly below that considered by the Japanese, which involves - the other conditions remaining wehanged - a much more accentuated amplitude of the liquid intumeseence proceeding toward the coast; 2) with the aggravating circumstance of a

(*) Of course, the slope may vary from one area to another. As far as the delta is concerned, for instanec, a faster increase of depth from the const towarl the open sea is observed "in the offehore strip from l'orto Caleri to I'unta della Maestra. More precisely, while the isobates up to 15 uns maintain themselves more or less at the sane distance frout the const, the isobates belween 15 and $25-30 \mathrm{~ms}$ progressively go away proceeding from North to South. In fact, the $25 \mathrm{~m}$ isobate North of P'unta delli Macstrit averages a distanec of $6 \mathrm{kmg}$ from the coust, and in the South it reaches a unxiumm of $11 \mathrm{kms}$ off Porto Folano" [Ciabalui (7), page 191]. This depends on the properties of the material dowing into the sea and on the action of the sea-currents. Thus, North of P'unta della Mrestra the ileposits have a less fine grain than in the South, while the larese sand area "develops toward North in a different nalure and a coarser grain. This fact surggests that the water-ways North of the l'o carry coarser material to the sea, of a clifferent nature, even if toward south a finer material earying by the subcoastal currents can be secn" $\left[\left({ }^{74}\right)\right.$, page 208$]$.

(**) On a front of soute $100 \mathrm{kms}$ the $50 \mathrm{~m}$ isobate is apart from the $40 \mathrm{~m}$ one by $25.50 \mathrm{kms}$; the area between the two isobates may therefore be considered a wide horizontal plain. 
jrogressive increase of the resonance effect as a consequence of the considerable sinking of the West coast since 1950, the other contitions remaining unchanged.

If we consider, for instanee, the high water occurred in Tenice between November 3 and 5, 1966, fig. 23 shows us that in those days the pressure variation was about $8 \mathrm{~mm}$ of mercury to which corresjondel, as is shown by fig. 24 , a lifting of the sea level of about $90 \mathrm{cms}$, that is about nine times the static valne!

d) As expressed in $\mathrm{X}$. 7, we lave an inversion of the air temperature trend on the Earth since 1940 , parallel to which an accentution of weather plienomena, particularly of rain happened.

Although these important phenomena are not reflected in what has been written and said about Fenice, it is a fact that the Magistrato alle Acque (Water control boart) ascertainet in the last decates always more frequent repetitions of weather precipitations in the area to the High Alriatic associated (N. 9.2); besides, the frequency and duration of winds was growing, especially the winds from SE-SSE (seiroceo), as is proved by tle $1 \mathrm{~g}$. 24 publisled by Prof. Giortani Soika, Director of the Meteorological Observatory of the Ospedale al Mare (Lido) and taken from $\left({ }^{18}\right)$. More recently [1970, v. $\left({ }^{73}\right)$, page 55] Giordani Soika and D. Meneglini stated that "tllese variations, which have been more accentuated and more signifieant in tle last fifteen years, express themselves in a heavy increase of the Bora wind in antumn (...) and in an increase of the Scirocco throughout summer and antumn". The anthors believe that this brought about an increase of the seiches. In this regard it must be believed - as is explained furtler - that the intesification of the phenomenon of free (or forcel) oscillations should not be attributed so much to the higher wind frequency but ratier to the accentuation of their first reason, identified in the variations of atmospheric pressure.

At ans rate, the accentuation of meteorological phenomena, linked to the inversion of the mean air temperature trend in the worlt since $19-10$, is accompaniel by an accentuation of the causes of perturbations of the sea level in connection with weatler events (*).

(*) Strietly speaking, in orier to obtain a ucan sea level that can he taken as a sure referenec, this should be corrected frou the alterations associatet with atmospheric pressure, with wint, evaporation, teuperature variations ete... not an easy task, inileed. The most sizeable alterations, 
This accounts for the interest of the studies of atmosphere and liydrosphere interaction.

It is still a widespread belief that the wind is a fundamental reason of the formation of free oscillations in liquid basins, either closed or open. It is often said that these oscillations appear when the wind suddenly mitigates its intensity, after laving blown for a long time in the same direction toward a coast. If this cause really exists, it is altogether casual and anyway of a secondary eflect. In the long yeurs dedicated to the study and observation of this phenomenon, I was able to prove that the chief cause, if not the only one, of the free oscillations ("seiches") can be found in the gralients of atmosplueric pressure. Quite often the transit of atmospherie pressure variations over a basin is accompanied by more or less high winıls and it is owing to this coincidence that one prefers to attach to the winds a great importance to the developing free or forced oscillations. This importance, lowever, is chiefly the ontcome of pressure perturbations; rather, sometimes the wind has a slackening eflect on existing oscillations $\left({ }^{30}\right)$.

When pressure variations, even of minimum extent, pass over any kind of basins, of the most diversified slapes, dimensions and deptls, they exeite there coperiodical oscillations, proper of the basins themselves $\left({ }^{5},{ }^{78}\right)$ or forced oscillations $\left({ }^{77}\right)$, also if there is no wint $\left({ }^{5}\right)$ or if winds are very wenk (figs. $1,2,3,6$ ). I lind the opportunity to

of enurse, are those linked to pressure, also beculse the wind is a consequenee As far as pressure variations are concerued, in order to eliminate corrections or to reduce them to a minimum, one uses to report to mean decennial values. Inwover, this is valid for static variations. In the case of air-sen interations in the field of resunance, such corrections are no longer valid: in any case they will be insulficient. The fact that in two eonsecutive decates the almospleric pressure averages vary of only tontlis of millibars does not justify the conclusion that the $7 \mathrm{~mm}$ did not beroure suliject to sizealle dynamie variations; when they are masked and aceraged, they lead to linm alterations which slould not happen in reality. A dynamic: alteration of the selected type in fig. 24 of an olongated form -- moreover masked in a complex recording as per fig. 23, is only partially comectet in nsual fractice. If these alterations increase then in the course of tinc, as in Venice and Porto Corsini, the mean sea level (valued with traditional methods) is hound to be fictive anl to change even uore with time. It is therefore more appropriate to define the mean sea level of the past decades as i mean apparent level. 
see this confirmed both in small closed basins and in wide seas. When the rliythm of pressure variation is very close to that of the free oscillations of the underlying water, the negligible barie gradients, in the order of fractions of Tor (and recorrlable, therefore, only with highly sensitive microbarographs), are sufficient to cause for lack of wind, large coperiodical movements in the basins $\left(^{5}\right)$. And such motions an liappen with a very wide range of rhythms, with periods from few tentlis of a second - which, if they take place on the surface of the two interacting meslia, misy originate the microseisms (r9) - to very slow ones which are able to put in motion all the water of a big lake (such as the Garda Lake which in the Summer and Autumn months, after formation of the surface of the thermal-leap, oseillates for weeks and weeks with periods of about 24 hours, that is of his internal binorlal exeited by the daily coperiodical barometrieal oscillation) (4).

Let us return now to the Adriatic.

In a recent study $\mathbf{F}$. Mlosetti, one of the most active and prolific experts of the so-calied "Comitatone", Accerboni fand Castelli looked into the influence of the wind on the lifting of the North Alriatic level by applying to that sea some modeis that had been already user by other authors on other basins ( $\left.{ }^{80}\right)$. The authors affirm that "the solution of the problem gives evirlence of the lifting of the level as an effect of the wind and of the consequent appearnoce of the seiches with periorls of about 21 hours, which are in perfect agreement with the observation" (1.e., jage 18). The appliation to the rough sea of November 3, 4, 5, 1966, referred to Venice, is summed up by fig. 26. Its cation says "if one neglects the effect of the seiches with an about lalf-daily period, which lave not been taken into account, a considerable correspondence of the two diagrams is noted" (l.e., page 29). Yet, this correspondence is only spjourent. Mosetti himself proves it in another work (done with the collaboration of MI. T. Currozzo), published in the same number of the "Bollettino di Geofisica" ( $\left.{ }^{76}\right)$. In it a new, truly officient method of tide analysis is presented. The anjulieation of this method to the latevy sea of exrly November 1966 led to the separation of the various components (fig. 2t). The figure gives full evidence that the high watcr at Tenice is largely associated to the intumescence which develops in approximately three days as a conseruence of the simultaneous reduction of atmospherie presswe and is enhanced by resonance phenomena, jrevailing the conditions set forth in $\mathbf{S}$. 6. It appears as an elongation conforming to the realled theory (fig. 12). $\Delta \mathrm{s}$ is shown by lig. 24, the principal intumescence is over- 
Iapped by an entire series of seiches. Clearly pretominant among these are the balf-daily ones, which develop with the characteristic of ample isolated impulses (tyjucal of open basins), while the oscilIations of about 22 hous, equally discontinuous, show limited amplitudes and overcame by the half-taily ones. In any case, the ones as well as the others are juxtified by the presence of coneriotimal pressine variations, which is evidenced by the barometrical curve of Fenice (fig. 23) $\left({ }^{*}\right)$.

Therefore, the pressure variations are sufficient to explain the phenomenon of high water in Venice, at least in its princijal as jerts. Aloreover, the figue 23 shows clearly that the wind was subject to stulden clanges of intensity and direction in several of the observation

(*) That the wind is no deteruninge factor in the formation of high waters is also provesl by the other heavy seas if due cousideration is given to the meteorologrienal comblitions in which they took place. J. Dorigo (s1)

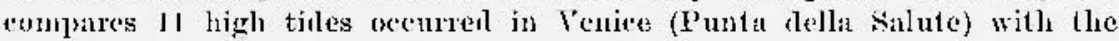
meteorolngical factors prevailing during them; $\Lambda$ pril 16, 1936: high water 147 cms, pressure at tide peak 742,5 mms, wind $54 \mathrm{kms} / \mathrm{h}$ from SSW (with it strong seaward roupouc'nt) (fig. 27a); Mlareh 12, 1937: high water 119,5 ems, pressure at tide peal $752,0 \mathrm{mms}$, wiml be kus il from the 3 rd puadrant, crosswise to the Adriatic; Dee, 5, 1946: high water 104 cms, peak presisure 746,8 ums, wind 24 kms/h from liNE; 1)e. 9, 1946: high water $136 \mathrm{cms}$, peak pressure $741,8 \mathrm{mms}$, light winl, from the $3 \mathrm{rd}$ and first guadiants; Nov. 29, 1947: high water 126,5 cuss, peak pressure 747,8 mus, very light winds $(8 \mathrm{kms} / \mathrm{h})$ from SSW; Jan. 27 , 1948: high water $119,5 \mathrm{cms}$, peak pres. sure $750 \mathrm{~mm}$, castern molerate winds; Jan. 28, 1948: hish waters 126 cums, peak pressure $7+2 \mathrm{~mm}$, wind $20 \mathrm{~km}$ s/h erosswise to the dariatie (W5W); Nov. 12, 1951: ligrl water 15] (ms (fir. 27ls), peak pressure 742 mus, wind 48 kms/h from SSW; Jee, 24, 1958: high water 124 ems, peal pressure 746,8 mms, sonth-wint 18 lims/li; Jatl. 15, 1960: high water 126 cus, peak pressure $750 \mathrm{mms}$, wind $34 \mathrm{kms} / \mathrm{h}$ from NE (thus teuding to depress the lmm); Oct. 15, 1960: high water $145 \mathrm{ems}$, peak pressure $748,2 \mathrm{mms}$, wind 48 kins/l from SSE (actually, on the whole winls prevailed from the $3 \mathrm{rd}$ fuadrant, moderate to almost stong; fig. 27c); Nov. 5, 1960: high water 123 enls, peak pressure $745,5 \mathrm{mms}$, nortl-wind 8 kms/h (figr. 27il).

The joint element of all these high tilles is exchsively the low pressure. The generally light wind blew from the most different lireetions.

The water is the higher the deeper is the reduction of atmospheric pressure, and therefore, the higher is its gradient bejore and after the minimum. and the oloser it approgehes to the resonano oonditions. This was exactly the case on Sovember 3, 4, 5, 1960 which nay he eonsidered, under such a standpoint, a linit ense. 
stations along the Arriatic West coast, so that its action gives rise to multiple solutions. That the seiches are not commected to the wind is proved by the fact that they are not present when the wind falls fas is affumed in page 32 of $\left.\left(^{(8)}\right)\right]$ but before it begius to blow from SR and when its local action is strongest, and that they reach maximum amplitules in agreement with overcame coperiodical proskure variations and of abrupt inversions of the pressure behavior, due to phenomena similar to those slown in figs. 1-6.

As a matter of fact, the frequency of high waters in the Venetian Lagoon increased strougly after 1951. The sudden alterations of the sea bottom in connection with the large flood of the same yoar and of following years which tended to raise the amplitude of sea motions and to lengthen the period of free oscillations of the IIigh Adriatic, the lifting of the water, due to reduced sall content, in floor periods which stimulater the intensification of water motions in the dynamic ficll, together with the reinforcement action following the sinking of the West cousts, both of which enhancer by meteorological perturbations, may well be summoned among the elief reasons of the alarming plienomenon.

In front of events of such grandiosity, the question should be raised up to which extent a limited work in the Lagoon may be able to counteract the heavy seas, when the latter appear with the amplitude proper to the open sea. The drama of Vonice must be seen, therefore, in the whole of natural plemomena which cannot be easily controlled by man. Iguoring this aspect of the problem, would be equivalent to renouncing a priori on a solution, incomplete as it may be.

REFER F N E S

See at prage 229 . 